Anna-Caterina Senn ${ }^{a, b}$, Stephan J. Hug ${ }^{a}$, Ralf Kaegi ${ }^{a}$, Janet G. Hering ${ }^{a, b, c}$, Andreas

9 Voegelin ${ }^{a}$ *

${ }^{a}$ Eawag, Swiss Federal Institute of Aquatic Science and Technology, Ueberlandstrasse 133,

CH-8600 Duebendorf, Switzerland

${ }^{\mathrm{b}}$ Department of Environmental Sciences, Institute of Biogeochemistry and Pollutant

Dynamics, ETH, Swiss Federal Institute of Technology, Zurich, Switzerland

${ }^{\mathrm{c}}$ School of Architecture Civil and Environmental Engineering, EPFL, École Polytechnique

Féderale de Lausanne, Switzerland

This document is the accepted manuscript version of the following article:

Senn, A. -C., Hug, S. J., Kaegi, R., Hering, J. G., \& Voegelin, A. (2018). Arsenate coprecipitation with $\mathrm{Fe}(\mathrm{II})$ oxidation products and retention or release during precipitate aging. Water Research, 131, 334-345. http://doi.org/10.1016/j.watres.2017.12.038

This manuscript version is made available under the CC-BY-NC-ND 4.0 license http://creativecommons.org/licenses/by-nc-nd/4.0/ 
The co-precipitation of arsenate (As(V)) with Fe(III)-precipitates is of great importance in water treatment and critically affects the fate of As in environmental systems. We studied the effects of dissolved phosphate $(\mathrm{P} ; 0-1 \mathrm{mM})$, silicate $(\mathrm{Si} ; 0$ or $0.5 \mathrm{mM})$ and $\mathrm{Ca}(0,0.5$ and $4 \mathrm{mM}$ ) on the sequestration of $7 \mu \mathrm{M} \mathrm{As}(\mathrm{V})$ by $\mathrm{Fe}(\mathrm{III})$-precipitates formed by the oxidation of $0.5 \mathrm{mM} \mathrm{Fe}(\mathrm{II})$ in aerated bicarbonate-buffered solutions with an initial $\mathrm{pH}$ of 7.0 as well as the retention or release of $\mathrm{As}(\mathrm{V})$ after precipitate aging for $30 \mathrm{~d}$ at $40{ }^{\circ} \mathrm{C}$. Dissolved $\mathrm{As}(\mathrm{V})$ concentrations in fresh precipitate suspensions greatly varied as a function of the initial dissolved $\mathrm{P} / \mathrm{Fe}$ ratio $\left((\mathrm{P} / \mathrm{Fe})_{\text {init }}\right)$ and the concentrations of $\mathrm{Ca}$ and $\mathrm{Si}$. Limited $\mathrm{As}(\mathrm{V})$ removal was observed at $(\mathrm{P} / \mathrm{Fe})_{\text {init }}$ that exceeded the critical ratio $(\mathrm{P} / \mathrm{Fe})_{\text {crit }}$ above which exclusively (Ca-)Fe(III)-phosphate forms. Effective $\mathrm{As}(\mathrm{V})$ removal was observed at $(\mathrm{P} / \mathrm{Fe})_{\text {init }}<(\mathrm{P} / \mathrm{Fe})_{\text {crit, }}$ where initial formation of (Ca-)Fe(III)-phosphate is followed by the formation of $\mathrm{Si}$ ferrihydrite in Si-containing electrolytes and of poorly-crystalline lepidocrocite and hydrous ferric oxide in the Si-free electrolytes. The retention of $\mathrm{As}(\mathrm{V})$ and $\mathrm{P}$ by fresh $\mathrm{Fe}(\mathrm{III})-$ precipitates was most effective in systems containing both $\mathrm{Ca}$ and $\mathrm{Si}$. In the $\mathrm{Si}$ - and $\mathrm{Ca}$-free electrolytes at $(\mathrm{P} / \mathrm{Fe})_{\text {init }}$ of $\sim 0.2-0.6$, the rapid onset of precipitate aging with conversion of $\mathrm{Fe}(\mathrm{III})$-phosphate to ferrihydrite resulted in a substantial remobilization of $\mathrm{As}(\mathrm{V})$ (up to 55\% of initially precipitated $\mathrm{As}(\mathrm{V}))$. Ca reduced As remobilization during aging by stabilizing CaFe(III)-phosphate and Si by stabilizing Si-ferrihydrite against transformation. Consequently, also after aging, the lowest dissolved $\mathrm{As}(\mathrm{V})$ and $\mathrm{P}$ fractions were observed in precipitate suspensions containing both $\mathrm{Ca}$ and $\mathrm{Si}$.

41 Keywords: arsenic removal; phosphate removal; iron precipitates; precipitate aging; water 42 treatment 


\section{INTRODUCTION}

Arsenic (As) occurs ubiquitously in soils, sediments and natural water. Owing to the high chronic toxicity of As, elevated As concentrations of geogenic or anthropogenic origin pose a serious threat to human health, especially via the consumption of As-containing drinking water and food. More than 100 million people worldwide rely on groundwater with toxic levels of geogenic As as drinking water resource (Smedley and Kinniburgh 2002), most of them in West Bengal (India), Bangladesh and Vietnam (Murcott 2012). In these regions, As-contaminated groundwater is also widely used for the irrigation of paddy rice and other crops, which leads to the accumulation of As in soils, As transfer into the food chain, and potentially also reduced crop yields (Dittmar et al. 2010a, Dittmar et al. 2010b, Melkonian et al. 2013, Panaullah et al. 2008).

The environmental fate and impact of As is tightly coupled to the cycling of Fe. Under anoxic conditions in soils and aquifers, the reductive dissolution of Fe(III)-(hydr)oxides with adsorbed As and phosphate $(\mathrm{P})$ and the reduction of strongly sorbing arsenate $(\mathrm{As}(\mathrm{V}))$ to less strongly sorbing arsenite (As(III)) result in elevated concentrations of dissolved As(III) and Fe(II) in soil porewater or groundwater (Roberts et al. 2010, Weber et al. 2010). When such waters are aerated, dissolved $\mathrm{Fe}(\mathrm{II})$ is oxidized to $\mathrm{Fe}(\mathrm{III})$ which forms poorly soluble $\mathrm{Fe}(\mathrm{III})-$ precipitates. The As(III) is (partly) co-oxidized to more strongly sorbing As(V) and (partly) removed from solution together with $\mathrm{P}$, silicate $(\mathrm{Si}), \mathrm{Ca}$ and other solutes by co-precipitation with Fe(III) (Hug and Leupin 2003, Roberts et al. 2004). Various Fe-based techniques for As removal from drinking water have been investigated, including co-oxidation and coprecipitation of As with naturally present or added Fe(II) (Hug et al. 2008, Meng et al. 2001, Roberts et al. 2004) or with Fe(II) produced via zerovalent Fe corrosion (Bang et al. 2005, Katsoyiannis et al. 2008, Leupin and Hug 2005, Nikolaidis et al. 2003, Su and Puls 2001b) or via electrocoagulation (Lakshmanan et al. 2009, Li et al. 2012, Ratna Kumar et al. 2004). 
The uptake of As by freshly formed Fe(III)-precipitates depends on the presence or absence of the co-precipitating solutes phosphate $(\mathrm{P})$ and silicate $(\mathrm{Si})$ and of the major cation Ca (Delaire et al. 2017, Meng et al. 2000, Meng et al. 2002, Roberts et al. 2004, Wilkie and Hering 1996) and their interdependent effects on precipitate structure and composition (Senn et al. 2015, Voegelin et al. 2010). Whereas phosphate strongly competes with As for uptake by $\mathrm{Fe}(\mathrm{III})$-precipitates, $\mathrm{Ca}$ promotes As removal via electrostatic interactions and by attenuating $\mathrm{P}$ competition through direct $\mathrm{Ca}-\mathrm{P}$ interactions. The co-precipitation of As with Fe(III)-precipitates has been examined in a large number of studies to date. However, much of this work has been performed in the context of the treatment of mineral processing wastes and addressed As uptake and retention by $\mathrm{Fe}(\mathrm{III})$-precipitates obtained from the forced hydrolysis of concentrated Fe(III) solutions (e.g., (Chen et al. 2009, Paktunc et al. 2008, Paktunc et al. 2015, Violante et al. 2007)). Studies concerned with As removal by Fe(III)precipitates formed by $\mathrm{Fe}(\mathrm{II})$ oxidation under conditions relevant for natural ground and surface waters or water treatment, on the other hand, either did not consider variations in Fe(III)-precipitate structure (Roberts et al. 2004) or examined only a limited set of conditions (van Genuchten et al. 2012, van Genuchten et al. 2014b, Voegelin et al. 2010). To date, studies that systematically link the extent of As co-precipitation with Fe oxidation products to variations in precipitate structure and chemical conditions are lacking.

The aging of fresh $\mathrm{Fe}(\mathrm{III})$-precipitates may result in structural transformations such as increasing polymerization and crystallization that can be associated with a loss of sorption capacity and consequently oxyanion release (Ford 2002, Fuller et al. 1993, Majzlan et al. 2007, Mayer and Jarrell 2000, Paktunc et al. 2008, Senn et al. 2017, Violante et al. 2007, Waychunas et al. 1993). This process is highly relevant with respect to the handling of residues from drinking water As removal and the fate of As associated with Fe(III)- 
on the transformation of $\mathrm{Fe}(\mathrm{II})$-derived $\mathrm{Fe}(\mathrm{III})$-precipitates and on $\mathrm{As}(\mathrm{V})$ retention during aging under conditions relevant for near-neutral ground- and surface waters have not been examined so far.

In an extensive experiment on the formation of $\mathrm{Fe}(\mathrm{III})$-precipitates via $\mathrm{Fe}(\mathrm{II})$ oxidation at near-neutral $\mathrm{pH}$ and the transformation of the fresh precipitates during aging, we characterized fresh and aged $\mathrm{Fe}(\mathrm{III})$-precipitates and identified the effects of $\mathrm{P}, \mathrm{Si}$ and $\mathrm{Ca}$ on precipitate structure, composition and aging (Senn et al. 2015, Senn et al. 2017), as summarized in Table 1: Marked changes in precipitate formation occur at initial dissolved $\mathrm{P} / \mathrm{Fe}$ ratios $(\mathrm{P} / \mathrm{Fe})_{\text {init }}$ around a critical ratio $(\mathrm{P} / \mathrm{Fe})_{\text {crit }}$ that depends on the background 102 electrolyte. At $(\mathrm{P} / \mathrm{Fe})_{\text {init }}>(\mathrm{P} / \mathrm{Fe})_{\text {crit, }}$, amorphous $\mathrm{Fe}(\mathrm{III})$-phosphate or $\mathrm{Ca}-\mathrm{Fe}(\mathrm{III})-$ phosphate 103 forms, the latter exhibiting a higher maximum precipitate $\mathrm{P} / \mathrm{Fe}$ ratio due to $\mathrm{Ca}-\mathrm{P}$ interactions. 104 At $(\mathrm{P} / \mathrm{Fe})_{\text {init }}<(\mathrm{P} / \mathrm{Fe})_{\text {crit }}$, the initial formation of $(\mathrm{Ca}-) \mathrm{Fe}(\mathrm{III})$-phosphate leads to the depletion of dissolved P. Subsequently, poorly-crystalline lepidocrocite and a ferrihydrite-type precipitate form in the Si-free electrolytes, and Si-rich ferrihydrite in the Si-containing

107 electrolytes with $(\mathrm{Si} / \mathrm{Fe})_{\text {init }}$ of 1 . Variations in precipitate structure are reflected in variations

108 in dissolved P. Starting from very low concentrations at $(\mathrm{P} / \mathrm{Fe})_{\text {init }}$ around $(\mathrm{P} / \mathrm{Fe})_{\text {crit }}$, dissolved $109 \mathrm{P}$ markedly increases with increasing $(\mathrm{P} / \mathrm{Fe})_{\text {init }}$ as the uptake capacity of the $(\mathrm{Ca}-) \mathrm{Fe}(\mathrm{III})-$ 110 phosphate is increasingly exceeded. Below $(\mathrm{P} / \mathrm{Fe})_{\text {crit }}$ in the absence of $\mathrm{Si}$, immediate onset of 111 (Ca-)Fe(III)-phosphate polymerization after dissolved $\mathrm{P}$ depletion leads to an increase in 112 dissolved $\mathrm{P}$ fractions with decreasing $(\mathrm{P} / \mathrm{Fe})_{\text {init. }}$ In the presence of $\mathrm{Si}$, the high sorption 113 capacity of Si-ferrihydrite inhibits the release of $\mathrm{P}$ within 4 hours after the onset of Fe(II) oxidation (Senn et al. 2015). Aging of the fresh precipitates for $30 \mathrm{~d}$ at $40{ }^{\circ} \mathrm{C}$ in their synthesis solutions induces marked structural changes (Senn et al. 2017). Most importantly,

116 the continuing polymerization of $\mathrm{Fe}(\mathrm{III})$ in (Ca-)Fe(III)-phosphate and ferrihydrite-type 117 precipitates leads to a decrease of the oxyanion sorption capacity of the precipitates and thus 
the remobilization of co-precipitated $\mathrm{P}$ (Senn et al. 2017). The extent of $\mathrm{P}$ remobilization

119 however is strongly dependent on the structure of the fresh precipitate and is lowest for

120 precipitates formed in the presence of $\mathrm{Ca}$ and $\mathrm{Si}$, due to the stabilizing effect of $\mathrm{Ca}$ on $\mathrm{Ca}$ -

$121 \mathrm{Fe}(\mathrm{III})$-phosphate and of Si on Si-ferrihydrite as well as due to Ca-phosphate formation.

122 The present study is based on our previous work on the effects of $\mathrm{P}, \mathrm{Si}$ and $\mathrm{Ca}$ on the

123 structure of fresh Fe(III)-precipitates, their transformation after 30 days of aging, and

124 consequences for P retention (Senn et al. 2015, Senn et al. 2017). Here we report on the

125 sequestration of a trace concentration of $\mathrm{As}(\mathrm{V})$ by the fresh and aged precipitates in the same

126 multifactorial experiment and on how As(V) sorption affects residual dissolved As(V).

127 Furthermore, we show results from a time-resolved 35-days Fe(III)-precipitate aging

128 experiment that provides insight into the time-dependence of $\mathrm{As}(\mathrm{V})$ and $\mathrm{P}$ release.

\section{MATERIALS AND METHODS}

\section{$130 \quad$ 2.1. Synthesis of fresh and aged precipitates with co-precipitated $A s(\mathbf{V})$}

131 Fresh and aged Fe(III)-precipitate suspensions were prepared from six background electrolytes $(\mathrm{Na}, \mathrm{Ca}$, low $\mathrm{Ca}, \mathrm{Mg}, \mathrm{Na}+\mathrm{Si}$ and $\mathrm{Ca}+\mathrm{Si})$ at twelve $\mathrm{P}$ concentrations as described previously (Senn et al. 2015, Senn et al. 2017). The precipitates were synthesized at an initial

$134 \mathrm{pH}$ of 7.0 by the oxidation of $0.5 \mathrm{mM} \mathrm{Fe}(\mathrm{II})$ in the presence of 0 to $1 \mathrm{mM} \mathrm{P}$, corresponding to

$135(\mathrm{P} / \mathrm{Fe})_{\text {init }}$ from $0-2$. The starting solutions contained $7 \mu \mathrm{M} \mathrm{As}(\mathrm{V})$, corresponding to an initial molar $\mathrm{As}(\mathrm{V}) / \mathrm{Fe}(\mathrm{II})$ ratio $\left((\mathrm{As} / \mathrm{Fe})_{\text {init }}\right)$ of 0.014 . To focus on the effects of $\mathrm{Fe}(\mathrm{III})$-precipitate formation and transformation on $\mathrm{As}(\mathrm{V})$ uptake and retention and to avoid the confounding effects of concomitant As(III) oxidation, all experiments reported here were conducted with

$139 \mathrm{As}(\mathrm{V})$. Treatment labels indicate the background electrolyte and $(\mathrm{P} / \mathrm{Fe})_{\text {init }}(\mathrm{e} . \mathrm{g}$., $\mathrm{Na} 0.05$ for 140 experiment in $\mathrm{Na}$ electrolyte at $(\mathrm{P} / \mathrm{Fe})_{\text {init }}$ of 0.05$)$. 
$142 \mathrm{CaCO}_{3}(\mathrm{Ca}), 0.5 \mathrm{mM} \mathrm{CaCO}$ and $7 \mathrm{mM} \mathrm{NaHCO}_{3}$ (low $\left.\mathrm{Ca}\right)$, or $4 \mathrm{mM} \mathrm{MgO}(\mathrm{Mg})$ in in high143 purity doubly deionized (DDI) water (18.2 M $\Omega \mathrm{cm}$, Milli- $\mathrm{Q}^{\circledR}$ Element, Millipore) purged 144 with $\mathrm{CO}_{2}$ gas. To prepare the $\mathrm{Si}$-containing electrolytes $(\mathrm{Na}+\mathrm{Si}, \mathrm{Ca}+\mathrm{Si}), 0.5 \mathrm{mM} \mathrm{Si}$ was 145 added from an alkaline stock solution (100 mM Si from $\mathrm{Na}_{2} \mathrm{SiO}_{3} \times 9 \mathrm{H}_{2} \mathrm{O}$, prepared daily) to 146 the slightly acidic $\mathrm{Na}$ and $\mathrm{Ca}$ electrolytes. The $\mathrm{pH}$ was then adjusted to $7.0( \pm 0.1)$ by purging 147 with pressurized air. After $\mathrm{pH}$ adjustment, $7 \mu \mathrm{M}(525 \mu \mathrm{g} / \mathrm{L}) \mathrm{As}(\mathrm{V})$ and $0-1 \mathrm{mM} \mathrm{P}(12$ concentrations) were spiked using $\mathrm{pH}$-neutral stock solutions $\left(13.35 \mathrm{mM} \mathrm{Na} 2 \mathrm{HAsO}_{4} \cdot 7 \mathrm{H}_{2} \mathrm{O}\right.$ and $50 \mathrm{mM} \mathrm{NaH}{ }_{2} \mathrm{PO}_{4} \cdot \mathrm{H}_{2} \mathrm{O}$; respectively). Fe oxidation and precipitation was initiated by 150 adding $0.5 \mathrm{mM} \mathrm{Fe}(\mathrm{II})$ using a daily prepared acidic stock solution $\left(50 \mathrm{mM} \mathrm{FeSO} \mathrm{F}_{4} \cdot 7 \mathrm{H}_{2} \mathrm{O}, 1\right.$ $\mathrm{mM} \mathrm{HCl}$ ). After thorough mixing, an unfiltered aliquot was collected to determine total initial element concentrations. Subsequently, the suspensions were left for $4 \mathrm{~h}$, with halfhourly remixing by turning the bottles upside down several times. After $4 \mathrm{~h}$ reaction time, the fresh suspensions were sampled by collecting unfiltered and filtered $(0.1 \mu \mathrm{m}$ cellulose nitrate 155 filter membranes) aliquots for the determination of total and dissolved element concentrations, respectively (and the solids for solid phase characterization). A duplicate set of fresh suspensions (after $4 \mathrm{~h}$ reaction time) was transferred into an oven and aged for 30 days at $40{ }^{\circ} \mathrm{C}$ before collection of unfiltered and filtered aliquots. During aging, the $\mathrm{pH}$ of the suspensions increased to $\mathrm{pH} 7.9 \pm 0.3$ due to $\mathrm{CO}_{2}$ outgassing (Senn et al. 2017), as it would

160 also occur in natural waters.

161 At $(\mathrm{P} / \mathrm{Fe}))_{\text {init }}$ of $0.25(0.56 \mathrm{mM} \mathrm{Fe})$, a time-resolved aging experiment was conducted in the $\mathrm{Na}, \mathrm{Na}+\mathrm{Si}, \mathrm{Ca}$ and $\mathrm{Ca}+\mathrm{Si}$ electrolytes. Initial sample preparation and $\mathrm{Fe}(\mathrm{II})$ oxidation was performed as described above, with $200 \mathrm{~mL}$ of solution in $300 \mathrm{~mL}$ polypropylene bottles. The initial solutions were sampled unfiltered and filtered. After $4 \mathrm{~h}$, filtered samples were collected again and the bottles were transferred to an oven set to $40^{\circ} \mathrm{C}$ to age the suspensions 
166 for 35 days. Filtered samples were collected up to 35 days aging time $(0.3,1,2,3,6,10,14$,

$16721,28,35 \mathrm{~d})$ for analysis of dissolved element concentrations and $\mathrm{pH}$.

\subsection{Determination of total and dissolved element concentrations}

For the determination of the concentrations of $\mathrm{Fe}, \mathrm{P}, \mathrm{As}, \mathrm{Si}, \mathrm{Na}, \mathrm{Ca}$ and $\mathrm{Mg}$ in the

170 unfiltered and filtered fresh and aged suspensions, the samples were acidified $\left(\mathrm{HNO}_{3}(\mathrm{Merck}\right.$, suprapure)) and diluted as required for analysis by inductively coupled plasma mass spectrometry (ICP-MS; Agilent 7500ce). The analysis of unfiltered initial solutions (after Fe(II) spike) and unfiltered final fresh and aged suspensions by ICP-MS indicated a high recovery of the spiked $\mathrm{As}(\mathrm{V})(>96 \%$ for $90 \%$ of the fresh suspensions; $>94 \%$ for $90 \%$ of aged suspensions) (Fig. $\mathrm{S} 1$ in supporting data). In the $\mathrm{Ca}$ and $\mathrm{Ca}+\mathrm{Si}$ electrolytes, we previously observed a decrease in $\mathrm{P}$ recovery from fresh to aged suspensions at the lowest and highest $(\mathrm{P} / \mathrm{Fe})_{\text {init, }}$, which we attributed to co-precipitation of $\mathrm{P}$ with Ca-carbonates or precipitation of Ca-phosphate on the walls of the reaction vessels (Senn et al. 2017). Analogous effects appeared to be negligible for As(V). their total concentration in the initial solution and the concentrations of As and P measured in the final filtered solutions $\left(\mathrm{As}_{\text {filt }}, \mathrm{P}_{\text {filt }}\right)$. This calculation was based on the assumption that $\mathrm{As}_{\text {filt }}$ and $\mathrm{P}_{\text {filt }}$ corresponded to the dissolved concentrations $\mathrm{As}_{\mathrm{soln}}$ and $\mathrm{P}_{\text {soln }}$, respectively, and that the concentration of dissolved $\mathrm{Fe}_{\text {soln }}$ was negligible. In some of the filtered solutions from fresh and aged $\mathrm{Na}$ and $\mathrm{Na}+\mathrm{Si}$ suspensions, however, measurable $\mathrm{Fe}$ concentrations indicated the presence of colloidal Fe. This observation was attributed to the stabilizing effects of $\mathrm{P}$ and

$187 \mathrm{Si}$ on $\mathrm{Fe}(\mathrm{III})$-colloids and the limited coagulating power of $\mathrm{Na}$ (Mayer and Jarrell 1996, Tessenow 1974) or to filter failure in two cases. To estimate the concentrations of colloidal As and $\mathrm{P}\left(\mathrm{As}_{\text {coll }}, \mathrm{P}_{\text {coll }}\right)$ in these electrolytes, it was assumed that the colloidal Fe-precipitates had the same $\mathrm{As} / \mathrm{Fe}$ and $\mathrm{P} / \mathrm{Fe}$ ratios as determined for the respective $\mathrm{Fe}(\mathrm{III})$-precipitates 
191 retained on the filter membranes and that the concentration of colloidal Fe corresponded to

$192 \mathrm{Fe}_{\text {filt. }}$. The dissolved concentrations $\mathrm{X}_{\text {soln }}(\mathrm{X}=\mathrm{As}$ or $\mathrm{P})$ were calculated by subtracting $\mathrm{X}_{\text {coll }}$

193 from $\mathrm{X}_{\text {filt }}$. This correction is further described in the supplementary data (Fig. S2). Because

194 dissolved As and $\mathrm{P}$ concentrations in the fresh $\mathrm{Na}+\mathrm{Si}$ electrolyte at $(\mathrm{P} / \mathrm{Fe})_{\text {init }} \leq 0.4$ were too

195 low for quantification, they were set to zero for data interpretation on a linear scale, and were 196 omitted in plots on a logarithmic scale.

\subsection{Model calculations}

A kinetic adsorption/co-precipitation model has been formulated by (Roberts et al. 2004)

199 to describe the removal of $\mathrm{Si}, \mathrm{P}, \mathrm{As}(\mathrm{V})$ and $\mathrm{As}(\mathrm{III})$ during $\mathrm{Fe}(\mathrm{II})$ oxidation and $\mathrm{Fe}(\mathrm{III})$

200 precipitation in aerated water. The model assumes that $\mathrm{Si}, \mathrm{P}$ and As competitively bind on a

201 single type of sorption site $\equiv \mathrm{Fe}$ whose concentration $[\equiv \mathrm{Fe}]$ is proportional to the total $\mathrm{Fe}$ (III)

202 concentration $[\mathrm{Fe}]_{\text {tot }}$ :

$203 \quad[\equiv \mathrm{Fe}]=S \times[\mathrm{Fe}]_{\text {tot }}$

$204 S$ representing the number of sorption sites per Fe. At equilibrium, this kinetic model 205 corresponds to a competitive Langmuir sorption model characterized by the site concentration $S \times[\mathrm{Fe}]_{\text {tot }}$ and the sorption coefficients $K_{x}$ for oxyanion uptake, where [ $\left.\equiv \mathrm{FeX}\right]$

207 and $[\mathrm{X}]$ denote the concentrations of the sorbed and dissolved oxyanion $\mathrm{X}$ :

$208 \equiv \mathrm{Fe}+X \rightleftarrows \equiv F e X$

$209 \quad K_{X}=\frac{[\equiv \mathrm{FeX}]}{[\equiv \mathrm{Fe}] \times[X]}$

210 This model was used to describe residual dissolved $\mathrm{As}(\mathrm{V})$ and $\mathrm{P}$ in the fresh precipitate 211 suspensions based on total initial concentrations of Fe, As(V), P and Si. For this purpose, the

212 model was set up in PhreeqC (Parkhurst and Appelo 1999) within PhreePlot (Kinniburgh and

213 Cooper 2016), and the non-linear least squares (modified Levenberg-Marquardt) procedure of

214 PhreePlot was used to derive the parameters $S$ and $K_{x}$ and their statistical uncertainty. Further

215 details on model calculations are provided in section 3.4. 


\section{RESULTS AND DISCUSSION}

\subsection{Dissolved As(V) concentrations in fresh suspensions}

The dissolved fractions of As in the fresh suspensions as a function of $(\mathrm{P} / \mathrm{Fe})_{\text {init }}$ for the six background electrolytes are shown in Figure 1, together with the data for P from (Senn et al. 2015). To facilitate the comparison of dissolved As fractions in the different fresh suspensions, the respective data are shown in an overlay plot in Figure 2a. To demonstrate major effects of $(\mathrm{P} / \mathrm{Fe})_{\text {init, }} \mathrm{Si}$ and $\mathrm{Ca}$ on $\mathrm{As}(\mathrm{V})$ removal and release, selected treatments are compared in Figure 3. Whereas the initial dissolved $\operatorname{As}(\mathrm{V})$ concentration $\left(\operatorname{As}(\mathrm{V})_{\text {init }}\right)$ was 7 $\mu \mathrm{M}$ in all treatments, the $\mathrm{P}$ concentrations $\left(\mathrm{P}_{\text {init }}\right)$ varied from 0 to $1 \mathrm{mM}$. Despite this difference, the fractions of dissolved As and $\mathrm{P}$ generally show similar trends. Changes in precipitate structure and dissolved $\mathrm{P}$ as a function of $(\mathrm{P} / \mathrm{Fe})_{\text {init }}$ and electrolyte type have been described in detail in earlier work (Senn et al. 2015) and are summarized in the introduction and in Table 1. Here, we focus on how dissolved $\mathrm{As}(\mathrm{V})$ was influenced by $(\mathrm{P} / \mathrm{Fe})_{\text {init }}$ and by the absence or presence of $\mathrm{Si}$ and $\mathrm{Ca}$.

At $(\mathrm{P} / \mathrm{Fe})_{\text {init }}$ above $(\mathrm{P} / \mathrm{Fe})_{\text {crit }}($ Table 1$)$, the oxyanion uptake capacity of amorphous (Ca)Fe(III)-phosphate was exceeded and residual dissolved As(V) increased markedly with increasing $(\mathrm{P} / \mathrm{Fe})_{\text {init }}($ Figure $2 \mathrm{a})$. Under these conditions, $\mathrm{As}(\mathrm{V})$ uptake did not depend on the absence or presence of $\mathrm{Si}$, but a strong effect of the electrolyte cation was observed, with markedly higher removal in the $\mathrm{Ca}$ and $\mathrm{Ca}+\mathrm{Si}$ electrolytes than in the $\mathrm{Na}$ and $\mathrm{Na}+\mathrm{Si}$ electrolytes. This difference was due to the higher oxyanion uptake capacity of Ca-Fe(III)phosphate as compared with Fe(III)-phosphate (Figure 1).

At intermediate $(\mathrm{P} / \mathrm{Fe})_{\text {init }}$, Ca strongly influenced $\mathrm{As}(\mathrm{V})$ sequestration via its effect on the oxyanion uptake capacity of amorphous $\mathrm{Ca}-\mathrm{Fe}(\mathrm{III})$-phosphate and thus on $(\mathrm{P} / \mathrm{Fe})_{\text {crit. }}$ (Note: We refer to these precipitates as $\mathrm{Ca}-\mathrm{Fe}(\mathrm{III})$-phosphate rather than $\mathrm{Ca}-\mathrm{Fe}(\mathrm{III})$ phosphate/arsenate because $\mathrm{P}$ is the dominant oxyanion and $\mathrm{As}(\mathrm{V})$ is only coprecipitated at 
molar $\mathrm{As}(\mathrm{V}) / \mathrm{P}$ ratios $<0.03$.) Below $(\mathrm{P} / \mathrm{Fe})_{\text {crit }}$, the very low dissolved fractions of $\mathrm{As}(\mathrm{V})$ in the Si-containing electrolytes (Figure 1c,d, Figure 2a) reflected its highly effective sorption by Si-rich ferrihydrite, whose fraction increased with decreasing $(\mathrm{P} / \mathrm{Fe})_{\text {init. }}$ In the Si-free

244 electrolytes, the fractions of residual dissolved $\mathrm{As}(\mathrm{V})$ increased as $(\mathrm{P} / \mathrm{Fe})_{\text {init }}$ decreased from

$245(\mathrm{P} / \mathrm{Fe})_{\text {crit }}$ to 0.05 (Figure 1a,e), as also observed for P (Figure 1b,f, Figure 2). This effect was 246 attributed to the immediate onset of precipitate aging after $\mathrm{Fe}(\mathrm{II})$ oxidation at $(\mathrm{P} / \mathrm{Fe})_{\text {init }}<$ $247(\mathrm{P} / \mathrm{Fe})_{\text {crit, }}$ as has previously been discussed for P (Mayer and Jarrell 2000, Senn et al. 2015, Voegelin et al. 2013) and As(V) (Fuller et al. 1993) release from Fe(III)-precipitates. In the Si-containing electrolytes, this effect was not observed (Figure 1c,d, Figure 2a) due to the inhibiting effects of $\mathrm{Si}$ (and $\mathrm{Ca}$ ) on precipitate transformation combined with the efficient uptake of any released $\mathrm{As}(\mathrm{V})$ and $\mathrm{P}$ by ferrihydrite (and Ca-phosphate precipitation).

In general, residual dissolved $\mathrm{As}(\mathrm{V})$ and $\mathrm{P}$ fractions in fresh suspensions exhibited similar trends (Figure 1). To directly compare $\mathrm{As}(\mathrm{V})$ and $\mathrm{P}$ uptake by fresh precipitates as a function of $(\mathrm{P} / \mathrm{Fe})_{\text {init }}$ and of $\mathrm{Si}$ and $\mathrm{Ca}$ in the electrolyte, molar precipitate $\mathrm{As} / \mathrm{P}$ ratios relative to the corresponding initial dissolved ratios $\left((\mathrm{As} / \mathrm{P})_{\mathrm{ppt}, \mathrm{rel}}=(\mathrm{As} / \mathrm{P})_{\mathrm{ppt}} /(\mathrm{As} / \mathrm{P})_{\text {init }}\right)$ are shown in Figure 4 for the $\mathrm{Na}, \mathrm{Ca}, \mathrm{Na}+\mathrm{Si}$ and $\mathrm{Ca}+\mathrm{Si}$ electrolytes. At low $(\mathrm{P} / \mathrm{Fe})_{\text {init }}$ in the $\mathrm{Na}$ and $\mathrm{Ca}$ electrolytes, uptake of As by poorly-crystalline lepidocrocite was slightly favored over P uptake. This effect was not observed in the $\mathrm{Na}+\mathrm{Si}$ and $\mathrm{Ca}+\mathrm{Si}$ electrolytes, where Si-rich ferrihydrite was the dominant precipitate. At intermediate $(\mathrm{P} / \mathrm{Fe})_{\text {init, }}(\mathrm{As} / \mathrm{P})_{\mathrm{ppt}, \mathrm{rel}}$ around unity 260 indicated that $\mathrm{As}(\mathrm{V})$ and $\mathrm{P}$ were taken up to similar extents in all electrolytes. At $(\mathrm{P} / \mathrm{Fe})_{\text {init }}>$ $261(\mathrm{P} / \mathrm{Fe})_{\text {crit }}$ in the $\mathrm{Na}$ and $\mathrm{Na}+\mathrm{Si}$ electrolytes, $\mathrm{P}$ exhibited a slight preference over $\mathrm{As}(\mathrm{V})$ for sequestration by Fe(III)-phosphate. The preference for $\mathrm{P}$ over $\mathrm{As}(\mathrm{V})$ was more pronounced for $\mathrm{Ca}-\mathrm{Fe}(\mathrm{III})$-phosphate formed in the $\mathrm{Ca}$ and $\mathrm{Ca}+\mathrm{Si}$ electrolytes, which was attributed to specific Ca-P interactions, including the formation of Ca-Fe(III)-phosphate and Ca-phosphate polymers (Senn et al. 2015). More specific Ca-P than $\mathrm{Ca}-\mathrm{As}(\mathrm{V})$ interactions can be 
rationalized by the observation that Ca-phosphates exhibit much lower solubilities than

267 structurally analogous Ca- arsenates (Voegelin et al. 2010) and the result from an adsorption study with goethite indicating a stronger enhancing effect of $\mathrm{Ca}$ on $\mathrm{P}$ than $\mathrm{As}(\mathrm{V})$ uptake (Gao and Mucci 2003).

\subsection{Dissolved $A s(V)$ in aged precipitate suspensions}

In Figure 5, the dissolved fractions of $\mathrm{As}$ and $\mathrm{P}$ in all aged electrolyte suspensions are shown in comparison to the fractions in the fresh suspensions. Dissolved fractions of As(V) in all aged suspensions are compared in an overlay plot in Figure 2b, the effects of $\mathrm{P}, \mathrm{Si}$, and

$\mathrm{Ca}$ on the residual dissolved fraction of As in selected treatments are shown in Figure 3.

At high $(\mathrm{P} / \mathrm{Fe})_{\text {init }}$ in the electrolytes without or with only $0.5 \mathrm{mM} \mathrm{Ca}(\mathrm{Na}, \mathrm{Na}+\mathrm{Si}, \mathrm{Mg}$ and low $\mathrm{Ca}$ electrolytes), the residual dissolved $\mathrm{As}(\mathrm{V})$ concentrations exhibited no significant changes from before to after aging (Figure 5a, e; Figure 3d). This was attributed to the stabilization of the precipitate towards Fe(III)-polymerization by the residual dissolved $\mathrm{P}$ in the aging suspension. In the presence of $4 \mathrm{mM}$ total $\mathrm{Ca}(\mathrm{Ca}, \mathrm{Ca}+\mathrm{Si}$ electrolytes), dissolved $\mathrm{As}(\mathrm{V})$ concentrations at high $(\mathrm{P} / \mathrm{Fe})_{\text {init }}$ decreased during aging, and an even stronger decrease was observed for $\mathrm{P}$ (Figure 5c,d). The decrease in dissolved As(V) may be due to coprecipitation of $\mathrm{As}(\mathrm{V})$ with Ca-phosphate which formed during aging (Senn et al. 2017), but could also be due to uptake of As by $\mathrm{Ca}-\mathrm{Fe}(\mathrm{III})$-phosphate from which $\mathrm{P}$ may have been depleted by Ca-phosphate precipitation. In the low $\mathrm{Ca}$ electrolyte, no decrease of the dissolved As(V) was observed during aging (Figure 5f) because the dissolved $\mathrm{Ca}$ concentration was too low to induce the formation of a Ca-phosphate precipitate (Senn et al. 2017).

At intermediate $(\mathrm{P} / \mathrm{Fe})_{\text {init }}$, the stabilizing effect of $\mathrm{Ca}$ on $\mathrm{Ca}-\mathrm{Fe}(\mathrm{III})-$ phosphate resulted in a markedly lower remobilization of As during aging than in the Ca-free treatments (Figure 2), 
especially at $(\mathrm{P} / \mathrm{Fe})_{\text {init }}$ between the $(\mathrm{P} / \mathrm{Fe})_{\text {crit }}$ of the $\mathrm{Na}$ and $\mathrm{Ca}$ electrolytes (e.g., $(\mathrm{P} / \mathrm{Fe})_{\text {init }}$ of 0.6 ; Figure 3c).

At low $(\mathrm{P} / \mathrm{Fe})_{\text {init }}$ in the Si-free electrolytes, aging led to substantial release of $\mathrm{As}(\mathrm{V})$ (Figure 2b, Figure 5a,e). Precipitate aging started immediately after Fe(II) oxidation was complete (Voegelin et al. 2013) and could already be detected in the fresh precipitate suspensions $4 \mathrm{~h}$ after Fe(II) addition (Senn et al. 2015) (Figure 2a). Again, the release of As $(\mathrm{V})$ was most pronounced in the $\mathrm{Na}$ background electrolyte, where at $(\mathrm{P} / \mathrm{Fe})_{\text {init }}$ between 0.1 and 0.2 , the dissolved fraction of As increased from $\sim 8 \%$ to $\sim 55 \%$ (Figure 2). The stabilizing effect of Si ferrihydrite at low $(\mathrm{P} / \mathrm{Fe})_{\text {init }}$ is reflected in the lower As remobilization in the $\mathrm{Na}+\mathrm{Si}$ electrolyte than in the $\mathrm{Na}$ electrolyte (Figure 2, Figure 5a, b). An even lower release was observed in the $\mathrm{Ca}+\mathrm{Si}$ electrolyte (Figure 2, Figure 5c), where $\mathrm{Ca}$ inhibited the transformation of Ca-Fe(III)-phosphate. In addition, Ca-phosphate precipitation may have attenuated the competition of any released As and $\mathrm{P}$ for sorption to $\mathrm{Ca}-\mathrm{Fe}(\mathrm{III})$-phosphate. $\mathrm{CO}_{2}$ outgassing that was partially compensated by continuing $\mathrm{Ca}$-carbonate precipitation in the $\mathrm{Ca}$ and $\mathrm{Ca}+\mathrm{Si}$ electrolytes at low $(\mathrm{P} / \mathrm{Fe})_{\text {init }}(\mathrm{Senn}$ et al. 2017) as well as by the continuing $\mathrm{Fe}(\mathrm{III})$ polymerization, especially in the $\mathrm{Na}$ electrolyte at intermediate $(\mathrm{P} / \mathrm{Fe})_{\text {init }}$. Considering that the adsorption of $\mathrm{As}(\mathrm{V})$ and $\mathrm{P}$ on pre-formed ferrihydrite decreases with increasing $\mathrm{pH}$ (Antelo et al. 2015, Dixit and Hering 2003), the increase in $\mathrm{pH}$ during aging may have contributed to drive $\mathrm{As}(\mathrm{V})$ and $\mathrm{P}$ release in some of the treatments. However, the extent of

$310 \mathrm{As}(\mathrm{V})$ and $\mathrm{P}$ release in our experiments and trends in $\mathrm{As}(\mathrm{V})$ and $\mathrm{P}$ release as a function of $311(\mathrm{P} / \mathrm{Fe})_{\text {init }}$ and background electrolyte composition suggest that ongoing $\mathrm{Fe}(\mathrm{III})$ polymerization and $\mathrm{Fe}(\mathrm{III})$-precipitate transformation were the main factors that caused $\mathrm{As}(\mathrm{V})$ and $\mathrm{P}$ release

313 during aging. 


\subsection{Time-resolved aging experiment}

To monitor the time-dependence of $\mathrm{As}(\mathrm{V})$ and $\mathrm{P}$ remobilization during aging, time

317 resolved experiments were conducted at $(\mathrm{P} / \mathrm{Fe})_{\text {init }}$ of 0.25 in $\mathrm{Na}, \mathrm{Na}+\mathrm{Si}, \mathrm{Ca}$ and $\mathrm{Ca}+\mathrm{Si}$ 318 electrolyte (Fig. 6). The data show that the marked release of $\mathrm{As}(\mathrm{V})$ and $\mathrm{P}$ in the $\mathrm{Na}$ and

$319 \mathrm{Na}+\mathrm{Si}$ electrolytes proceeds within the first days after $\mathrm{Fe}(\mathrm{II})$ oxidation and approaches a 320 plateau after 7-10 days. The $\mathrm{pH}$ increased from initially 7.0 to 7.8-8.2 after 35 days of aging, in line with $\mathrm{pH}$ values in aged suspensions from the multifactorial experiment (Senn et al. 2017).

Interestingly, the dissolved fractions of $\mathrm{As}(\mathrm{V})$ and $\mathrm{P}$ in the $\mathrm{Ca}$ electrolyte initially increased due to remobilization, but started to decrease again after $\sim 21$ and $\sim 10$ days, respectively. We attribute these trends to the precipitation of Ca-phosphate and $\mathrm{Ca}$-carbonate (as indicated by trends in dissolved $\mathrm{Ca}$ ) and co-precipitation of $\mathrm{As}(\mathrm{V})$ and $\mathrm{P}$. In the $\mathrm{Ca}+\mathrm{Si}$ electrolyte, the slow increase in dissolved $\mathrm{As}(\mathrm{V})$ and $\mathrm{P}$ may be due to concomitant oxyanion release from slowly transforming $\mathrm{Fe}(\mathrm{III})$-precipitates and co-precipitation with $\mathrm{Ca}$. The interplay between the aging of the Fe(III)-precipitates and related remobilization of $\mathrm{As}(\mathrm{V})$ and $\mathrm{P}$ and the concomitant formation of Ca-phases that may re-sequester released $\mathrm{As}(\mathrm{V})$ and P may have important environmental implications and warrants further study.

\subsection{Modeling residual dissolved $A s(V)$ and $P$ in fresh precipitate suspensions}

In a study on the removal of $\mathrm{As}(\mathrm{III})$ and $\mathrm{As}(\mathrm{V})$ by co-oxidation and co-precipitation with

$334 \mathrm{Fe}(\mathrm{II})$ in synthetic Bangladesh groundwater (SBGW), Roberts et al. (2004) developed a

335 kinetic competitive oxyanion co-precipitation model to describe residual dissolved As 336 concentrations. The same model was applied by Berg et al. (2006) to rationalize results from 337 a study on As(III) and As(V) removal in sand filters in Vietnam. More recently, the same 338 approach was implemented in a kinetic model to describe the removal of As(III) by 339 electrocoagulation ( $\mathrm{Li}$ et al. 2012). We used an equilibrium formulation of the same model 
that corresponds to a one-site competitive Langmuir sorption model to describe residual

341 dissolved $\mathrm{As}(\mathrm{V}), \mathrm{P}$ and $\mathrm{Si}$ in the fresh precipitate suspensions based on the initial total concentration of $\mathrm{As}(\mathrm{V}), \mathrm{P}, \mathrm{Si}$ and Fe. Model parameters were optimized by minimizing the sum of the squared residuals between experimental and modeled concentrations of dissolved As(V) (multiplied by 100 to give weight similar to P and Si), P and Si. Because the model does not account for the incipient precipitate transformation and oxyanion release observed in the $\mathrm{Si}$-free electrolytes at $(\mathrm{P} / \mathrm{Fe})_{\text {init }}<0.4$, the respective data was excluded from modeling.

Model parameters from a first fit with a single site capacity and a single set of sorption coefficients for all treatments were comparable to parameters reported by Roberts et al. (2004) (Table 2). In both studies, about 0.2 units higher $\log K_{P}$ than $\log K_{A s}$ values indicated a slight preference for uptake of $\mathrm{P}$ over $\mathrm{As}(\mathrm{V})$, in line with $(\mathrm{As} / \mathrm{P})_{\mathrm{ppt}, \text { rel }}<1$ at high $(\mathrm{P} / \mathrm{Fe})_{\text {init }}$ reported in Figure 4. To account for the difference in the oxyanion uptake capacity of precipitates formed in the electrolytes with high $\mathrm{Ca}(\mathrm{Ca}, \mathrm{Ca}+\mathrm{Si})$, with low $\mathrm{Ca}$ or $\mathrm{Mg}$, or no $\mathrm{Ca}$ or $\mathrm{Mg}(\mathrm{Na}$ and $\mathrm{Na}+\mathrm{Si})$ and potential differences in oxyanion sorption affinity, the data from the respective sets of samples were also fit separately (Table 2; fitted $\mathrm{As}(\mathrm{V})$ and $\mathrm{P}$ fractions shown in Fig. 1). This approach allowed for a significantly more accurate description of the experimental data (decrease of SSR from 0.279 to 0.055 ). The much higher site concentration for the $\mathrm{Ca} / \mathrm{Ca}+\mathrm{Si}$ electrolytes than the $\mathrm{Mg} /$ low $\mathrm{Ca}$ electrolytes reflected the formation of Ca-phosphate and $\mathrm{Ca}-\mathrm{Fe}(\mathrm{III})-$ phosphate polymers in the $\mathrm{Ca}$ and $\mathrm{Ca}+\mathrm{Si}$ electrolytes. The sorption coefficients pointed to variations in the relative sorption affinities of As and $\mathrm{P}$ :

360 Whereas no marked preference for $\mathrm{P}$ over As was observed for the $\mathrm{Na} / \mathrm{Na}+\mathrm{Si}$ and $\mathrm{Mg} / \mathrm{low}$

$361 \mathrm{Ca}$ electrolytes, the presence of $4 \mathrm{mM} \mathrm{Ca}$ in the $\mathrm{Ca} / \mathrm{Ca}+\mathrm{Si}$ electrolytes resulted in a markedly higher difference between $\log \mathrm{K}_{\mathrm{P}}$ and $\log \mathrm{K}_{\mathrm{As}}$ that reflects the preference of $\mathrm{Ca}$ for complexation with P rather than $\mathrm{As}(\mathrm{V})$ (van Genuchten et al. 2014a). Since the enhanced

364 uptake of $\mathrm{P}$ in the $\mathrm{Ca} / \mathrm{Ca}+\mathrm{Si}$ electrolytes is not solely due to co-precipitation with $\mathrm{Fe}(\mathrm{III})$, 
365 but also due to precipitation of Ca-phosphate polymers, the sorption coefficient $K_{P}$ must 366 however be interpreted with care.

367 Because the model parameters were refined based on residual dissolved concentrations 368 on a linear scale, the fits were mainly sensitive to treatments with high residual dissolved P 369 and $\mathrm{As}(\mathrm{V})$ fractions, i.e., treatments at high $(\mathrm{P} / \mathrm{Fe})_{\text {init }}$ in which $(\mathrm{Ca}-) \mathrm{Fe}(\mathrm{III})$-phosphate formed and $\mathrm{As}(\mathrm{V})$ and $\mathrm{P}$ sequestration occurred via co-precipitation rather than adsorption at the surface of an Fe(III)-(hydr)oxide. Although it might be more appropriate to describe these coprecipitates with a solubility product, such an approach is complicated by the fact that the phase composition and thus the solubility product itself depend on solution chemistry

374 (Stumm et al. 1962, van der Grift et al. 2016). In a study on P removal from wastewater, variations in the $(\mathrm{P} / \mathrm{Fe})_{\mathrm{ppt}}$ of amorphous $\mathrm{Fe}(\mathrm{III})$-phosphate were accounted for by modeling the precipitation of a $\mathrm{Fe}(\mathrm{III})-$ phosphate with $(\mathrm{P} / \mathrm{Fe})_{\mathrm{ppt}}$ of 0.4 combined with $\mathrm{P}$ adsorption to the Fe(III)-phosphate (Luedecke et al. 1989). In our sorption model, variations in the number of free adsorption sites provide some flexibility to account for variations in the oxyanion uptake of $(\mathrm{Ca}-) \mathrm{Fe}(\mathrm{III})-$ phosphate as a function of $(\mathrm{P} / \mathrm{Fe})_{\text {init }}$ and resulting variations in residual dissolved $\mathrm{P}$ and $\mathrm{As}(\mathrm{V})$.

At $(\mathrm{P} / \mathrm{Fe})_{\text {init }}<(\mathrm{P} / \mathrm{Fe})_{\text {crit }}$ in the Si-containing fresh electrolytes where Si-ferrihydrite was the dominant precipitate type and precipitate aging was still limited, measured dissolved $\mathrm{As}(\mathrm{V})$ and $\mathrm{P}$ fractions were close to $0 \%$ on a linear scale (Figure $1 \mathrm{c}, \mathrm{d})$. The model, on the other hand, predicted concentrations in the low percent range, overestimating the dissolved $\mathrm{As}(\mathrm{V})$ and $\mathrm{P}$ relative to measured concentrations. This suggests that $\mathrm{As}(\mathrm{V})$ and $\mathrm{P}$ sorption to ferrihydrite results in lower dissolved $\mathrm{As}(\mathrm{V})$ and $\mathrm{P}$ concentrations than expected for solubility control by (Ca-)Fe(III)-phosphate.

To obtain an adequate description of dissolved $\mathrm{As}(\mathrm{V})$ and $\mathrm{P}$ concentrations over wide ranges in solution concentrations on a logarithmic scale, a multi-component model 
accounting for the formation of different phases with different sorption site concentration and sorption affinities would be required. In addition to oxyanion uptake by different Fe(III)precipitate types and the influence of cations, such a kinetic model would also have to account for $\mathrm{Fe}(\mathrm{III})$-precipitate transformation processes and concomitant oxyanion release,

Ca-phosphate and Ca-carbonate precipitation, and related $\mathrm{As}(\mathrm{V})$ and $\mathrm{P}$ re-precipitation.

\subsection{Comparison of residual dissolved $\mathrm{As}(\mathrm{V})$ and $\mathrm{P}$ fractions with previous studies}

In Figure 7, the residual fractions of $\mathrm{As}(\mathrm{V})$ and $\mathrm{P}$ from the fresh $\mathrm{Na}+\mathrm{Si}$ and $\mathrm{Ca}+\mathrm{Si}$ suspensions are shown together with data from Roberts et al. (2004). This study examined the removal of $6.7 \mu \mathrm{M} A s(\mathrm{~V})$ or $\mathrm{As}(\mathrm{III})$ from synthetic Bangladesh groundwater with constant $\mathrm{Si}$ and $\mathrm{P}(2.5 \mathrm{mM} \mathrm{Ca} ; 1.5 \mathrm{mM} \mathrm{Mg} ; 1.07 \mathrm{mM} \mathrm{Si} ; 0.097 \mathrm{mM} \mathrm{P} ; \mathrm{pH} \sim 7)$ as a function of single additions of 0.9 to $0.04 \mathrm{mM} \mathrm{Fe}(\mathrm{II})$ (corresponding to increasing $(\mathrm{P} / \mathrm{Fe})_{\text {init) }}$ ). At $(\mathrm{P} / \mathrm{Fe})_{\text {init }}$ of $\sim 0.2$, initial dissolved $\mathrm{P}$ and $\mathrm{Fe}(\mathrm{II})$ concentrations in the present work and in Roberts et al. (2004) as well as the respective $(\mathrm{As}(\mathrm{V}) / \mathrm{Fe})_{\text {init }}$ were similar, but the $(\mathrm{Si} / \mathrm{Fe})_{\text {init }}$ in the current study (1.0) was lower than the ( $\mathrm{Si} / \mathrm{Fe})_{\text {init }}$ of $\sim 2.2$ in Roberts et al. (2004). In the present study, $(\mathrm{P} / \mathrm{Fe})_{\text {init }}$ up to $\sim 2$ at constant $(\mathrm{Si} / \mathrm{Fe})_{\text {init }}$ of 1.0 and $(\mathrm{As}(\mathrm{V}) / \mathrm{Fe})_{\text {init }}$ of 0.014 were obtained by increasing initial $\mathrm{P}_{\text {diss }}$ up to $1 \mathrm{mM}$. In contrast, Roberts et al. (2004) achieved an increase in $(\mathrm{P} / \mathrm{Fe})_{\text {init }}$ up to 2.3 by decreasing the amount of spiked $\mathrm{Fe}(\mathrm{II})$ down to $0.04 \mathrm{mM}$, which resulted in a concomitant increase of $(\mathrm{Si} / \mathrm{Fe})_{\text {init }}$ up to 25 and $\left.(\mathrm{AsV}) / \mathrm{Fe}\right)_{\text {init }}$ or $(\mathrm{As}(\mathrm{III}) / \mathrm{Fe})_{\text {init }}$ up to 0.16 (Table S1). Despite these experimental differences, trends in residual dissolved As(V) and $\mathrm{P}$ fractions reported by Roberts et al. (2004) as a function of $(\mathrm{P} / \mathrm{Fe})_{\text {init }}$ fall between the

410 trends observed for the $\mathrm{Na}+\mathrm{Si}$ and $\mathrm{Ca}+\mathrm{Si}$ electrolytes (Figure 7), suggesting that the $(\mathrm{P} / \mathrm{Fe})_{\text {init }}$

411 ratio is suitable to compare results obtained over a range in $\mathrm{P}$ and $\mathrm{Fe}$ concentrations.

412 Although the synthetic groundwater used by Roberts et al. (2004) contained $2.5 \mathrm{mM} \mathrm{Ca}$,

413 dissolved $\mathrm{As}(\mathrm{V})$ and $\mathrm{P}$ concentrations are more similar to the values from the $\mathrm{Na}+\mathrm{Si}$ (with no $414 \mathrm{Ca}$ ) than the $\mathrm{Ca}+\mathrm{Si}$ treatment (with $4 \mathrm{mM} \mathrm{Ca}$ ), suggesting that specific Ca-phosphate 
interactions were less relevant than in the $\mathrm{Ca}+\mathrm{Si}$ electrolyte. This difference can be explained

416 by the increase of $\mathrm{P}_{\text {init }}$ up to $1 \mathrm{mM}$ in the $\mathrm{Ca}+\mathrm{Si}$ electrolyte, as compared to a constant $\mathrm{P}_{\text {init }}$ of

$417 \sim 0.097$ in the experiments of Roberts et al. (2004), which corresponds to a much higher

418 saturation index for Ca-phosphates in the current work than in Roberts et al. (2004). This

419 interpretation is in line with the finding that the extent of $\mathrm{P}$ precipitation during groundwater aeration also depends on the degree of Ca-phosphate supersaturation (Griffioen 2006). Furthermore, the groundwater used by Roberts et al. (2004) contained $1.6 \mathrm{mM} \mathrm{Mg}$ that may inhibit the precipitation of Ca-phosphate (Brown 1981).

The comparison of the residual dissolved As in experiments with As(III) and As(V) from Roberts et al. (2004) illustrates the much lower affinity of As(III) than As(V) for coprecipitation during Fe oxidation and precipitation (Figure 7). Residual As and $\mathrm{P}$ fractions from a study on As(III) removal from synthetic groundwater by electrocoagulation (Li et al. 2012) are shown in Figure 7 for comparison as well (6.7 $\mu \mathrm{M}$ As(III); $0.097 \mathrm{mM}$ P, $1.07 \mathrm{mM}$

Si, $2.5 \mathrm{mM} \mathrm{CaCl}_{2}, 1.6 \mathrm{mM} \mathrm{MgCl}_{2}, 8.2 \mathrm{mM} \mathrm{NaHCO}_{3}$, $\mathrm{pH} 7.2$ ). In this study, 0.6 to $0.06 \mathrm{mM}$ $\mathrm{Fe}(\mathrm{II})$ were added at a rate of $0.016 \mathrm{mM} / \mathrm{min}$ through electrolytic dissolution of elemental $\mathrm{Fe}$, corresponding to $(\mathrm{P} / \mathrm{Fe})_{\text {init }}$ from $\sim 0.16$ to $\sim 1.5$. The respective data for residual dissolved $\mathrm{P}$ closely match with data from Roberts et al. (2004), but the data for residual As point to more

effective removal by continuous Fe(II) addition. This can be attributed to the slow release of $\mathrm{Fe}(\mathrm{II})$ during electrocoagulation, which leads to the formation of solids with higher oxyanion/Fe ratios and to more effective oxidation of $\mathrm{As}(\mathrm{III})$ to $\mathrm{As}(\mathrm{V})$ (Li et al. 2012), in line with observations by Roberts et al. (2004) for incremental versus single Fe(II) additions.

\subsection{Environmental implications}

This study showed how variations in solution chemistry affect As(V) sequestration by fresh $\mathrm{Fe}(\mathrm{III})$-precipitates and how precipitate transformation during aging promotes $\mathrm{As}(\mathrm{V})$ resolubilization. In Figure 2cd, the concentrations of dissolved $\mathrm{As}(\mathrm{V})$ in fresh and aged 
440 suspensions are shown on a logarithmic scale to visualize the main effects of $(\mathrm{P} / \mathrm{Fe})_{\text {init }}, \mathrm{Ca}$ 441 and $\mathrm{Si}$ on $\mathrm{As}(\mathrm{V})$ sequestration by fresh and aged precipitates and for comparison with 442 drinking water guideline values. By inducing the formation of ferrihydrite that is stabilized 443 against further polymerization (Mayer and Jarrell 2000, Senn et al. 2015, Senn et al. 2017,

444 Voegelin et al. 2010), the presence of Si markedly reduces residual As(V) concentration at 445 low $(\mathrm{P} / \mathrm{Fe})_{\text {init }}$ to values below the WHO guideline value of $10 \mu \mathrm{g} / \mathrm{L}$ (indicated by green arrow 446 in Figure 2c). The impact of $\mathrm{Ca}$ is of particular importance at intermediate $(\mathrm{P} / \mathrm{Fe})_{\text {init }}$, as it 447 enhances the oxyanion uptake of the Fe(III)-precipitates through favorable electrostatic 448 interactions, specific $\mathrm{Ca}-\mathrm{P}$ interactions and by stabilizing the precipitates, especially Ca$449 \mathrm{Fe}(\mathrm{III})$-phosphate, against transformation. In natural waters, however, the effect of Ca may be 450 smaller than observed in this study, because $\mathrm{Ca}$ and $\mathrm{P}$ concentrations are often lower and $\mathrm{Mg}$ 451 or other solutes may inhibit Ca-phosphate precipitation.

452 Compared to average and median concentrations of Fe $(3.4$ and $1.1 \mathrm{mg} / \mathrm{L} ; \mathrm{n} \sim 3500)$ and 453 $\mathrm{P}(0.7$ and $0.3 \mathrm{mg} / \mathrm{L})$ in groundwaters from Bangladesh, the Fe $(28 \mathrm{mg} / \mathrm{L})$ and $\mathrm{P}(0.7-31$ $454 \mathrm{mg} / \mathrm{L}$ ) concentrations in our experiments were rather high. The median and 5-95 percentile 455 range of the $\mathrm{P} / \mathrm{Fe}$ ratio $(0.25$ and $0.02-5)$ of these groundwaters, on the other hand, which is 456 of critical importance in As removal (Hug et al. 2008), relatively closely matched the range 457 of $(\mathrm{P} / \mathrm{Fe})_{\text {init }}(0-2)$ probed in our experiments. Compared to the $(\mathrm{Si} / \mathrm{Fe})_{\text {init }}$ of 1.0 in the $\mathrm{Na}+\mathrm{Si}$ and $\mathrm{Ca}+\mathrm{Si}$ electrolytes, the $\mathrm{Si} / \mathrm{Fe}$ ratios of Bangladesh groundwaters tend to be much higher 459 (minimum 0.8, median 35). The average concentration of $\mathrm{Ca}(52 \mathrm{mg} / \mathrm{L})$ in Bangladesh 460 groundwaters lies between the $\mathrm{Ca}$ concentrations in the $\mathrm{Ca} / \mathrm{Ca}+\mathrm{Si}$ electrolytes $(160 \mathrm{mg} / \mathrm{L}$ $461 \mathrm{Ca})$ and the low $\mathrm{Ca}$ electrolyte $(20 \mathrm{mg} / \mathrm{L})$. Thus, based on typical concentrations of Fe, P, Si 462 and $\mathrm{Ca}$ in anoxic As-containing groundwaters from Bangladesh (BGS and DPHE 2001), 463 Vietnam and Cambodia (Hug et al. 2008), precipitates formed during groundwater 464 oxygenation are expected to range from Si-rich ferrihydrite to Ca-containing $\mathrm{Fe}(\mathrm{III})$ - 
phosphate, and results from the low $\mathrm{Ca}$ and $\mathrm{Ca}+\mathrm{Si}$ electrolytes are most directly applicable to infer the extent of $\mathrm{As}(\mathrm{V})$ sequestration by fresh and aged precipitates in field systems.

High $\mathrm{P} / \mathrm{Fe}$ ratios that are frequently found in Bengali groundwaters pose special difficulties for As removal (Hug et al. 2008) and require techniques that involve the addition of supplementary Fe, either as dissolved Fe(II) (Meng et al. 2001, Roberts et al. 2004), through corrosion of zerovalent iron (ZVI) (Leupin et al. 2005, Su and Puls 2001a) or via and electrocoagulation (Lakshmanan et al. 2009, Li et al. 2012, Ratna Kumar et al. 2004). With respect to such systems, the $\mathrm{Fe}(\mathrm{II})$ concentration of $0.5 \mathrm{mM}$ used in the present study falls well into the technically relevant range.

During the aging of the precipitate suspensions for 30 days at $40^{\circ} \mathrm{C}$, dissolved $\mathrm{As}(\mathrm{V})$ concentrations in (nearly) all treatments remained stable or increased to levels above the WHO guideline value (Figure $2 \mathrm{~d}$ ). Nevertheless, at intermediate and low $(\mathrm{P} / \mathrm{Fe})_{\text {init }}, \mathrm{Ca}$ and $\mathrm{Si}$ exhibited markedly inhibited precipitate transformation and $\mathrm{As}(\mathrm{V})$ release. However, both $\mathrm{Ca}$ and $\mathrm{Si}$ were required to prevent $\mathrm{As}(\mathrm{V})$ re-solubilization to levels above the Bengali drinking water guideline value of $50 \mu \mathrm{g} / \mathrm{L}$. With respect to the operation of drinking water treatment systems for As removal and the handling of treatment residues, our data show that fresh Fe(III)-precipitates may effectively reduce dissolved As, but that transformation of fresh precipitates to more polymerized or crystalline solids with lower oxyanion sorption capacity may result in substantial release of temporarily retained As within a time period of a few days to few weeks. On the other hand, the results also point to the importance of Ca-precipitate formation for longer-term $\mathrm{As}(\mathrm{V})$ retention.

The results from this study are not only of importance with respect to Fe-based As(V) removal from drinking water, but also contribute to a better understanding of As dynamics in agricultural fields and especially rice paddies irrigated with As-rich groundwater. In these systems, Fe(III)-precipitate formation and transformation not only impact the introduction of 
490 As into the soils (Dittmar et al. 2007, Roberts et al. 2007), but also As accumulation around

491 rice roots (Frommer et al. 2011) as well as As accumulation in soils and release during 492 monsoon flooding (Dittmar et al. 2010b, Roberts et al. 2010).

\section{CONCLUSIONS}

This study reveals how $\mathrm{Si}, \mathrm{P}$ and $\mathrm{Ca}$, via their effects on $\mathrm{Fe}(\mathrm{III})$-precipitate structure and ion co-sorption, critically influence the uptake of $\mathrm{As}(\mathrm{V})$ by fresh and aged $\mathrm{Fe}(\mathrm{III})$ precipitates. Variations in the extent of $\mathrm{As}(\mathrm{V})$ sequestration can be rationalized in terms of competitive oxyanion uptake and the structural diversity of the precipitating $\mathrm{Fe}(\mathrm{III})$-solids. The results highlight the important roles of $\mathrm{Ca}$ and $\mathrm{Si}$ in promoting $\mathrm{As}(\mathrm{V})$ removal by fresh precipitates and $\mathrm{As}(\mathrm{V})$ retention during precipitate aging and indicate that results from studies in simplified Na-electrolytes must be considered with care with respect to their transferability to natural waters containing $\mathrm{Ca}$ and $\mathrm{Si}$.

A simple single-phase sorption model is adequate to describe residual dissolved $\mathrm{As}(\mathrm{V})$ in fresh suspensions under conditions where saturation of the oxyanion uptake capacity limits removal. To describe the solubility of $\mathrm{As}(\mathrm{V})$ and other oxyanions under conditions where the sorption capacity of the Fe(III)-precipitates is not reached, a more complex kinetic modeling approach would be required that accounts for the structural diversity of fresh precipitates, their transformation over time, and the concomitant formation of Ca-phases.

\section{ACKNOWLEDGEMENTS}

509 Irene Brunner, Thomas Rüttimann and Numa Pfenninger (Eawag, Switzerland) are 510 acknowledged for assistance with laboratory experiments and analyses. This project was

511 financially supported by the Swiss National Science Foundation under contracts No. 200021512132123 and 200020-152993. 
Antelo, J., Arce, F. and Fiol, S. (2015) Arsenate and phosphate adsorption on ferrihydrite nanoparticles. Synergistic interaction with calcium ions. Chemical Geology 410, 53-62.

Bang, S., Korfiatis, G.P. and Meng, X. (2005) Removal of arsenic from water by zero-valent iron. Journal of Hazardous Materials 121(1-3), 61-67.

Berg, M., Luzi, S., Trang, P.T.K., Viet, P.H. and Giger, W. (2006) Arsenic removal from groundwater by household sand filters: Comparative field study, model calculations, and health benefits. Environmental Science and Technology 40, 5567-5573.

BGS and DPHE (2001) Arsenic contamination of groundwater in Bangladesh. Kinniburgh, D.G. and Smedley, P.L. (eds), British Geological Survey (BGS) \& Bangladesh Department for Public Health Engineering (DPHE), Keyworth, UK.

Brown, J.L. (1981) Calcium phosphate precipitation: Effects of common and foreign ions on hydroxyapatite crystal growth. Soil Science Society of America Journal 45, 482-486.

Chen, N., Jiang, D.T., Cutler, J., Kotzer, T., Jia, Y.F., Demopoulos, G.P. and Rowson, J.W. (2009) Structural characterization of poorly-crystalline scorodite, iron(III)-arsenate coprecipitates and uranium mill neutralized raffinate solids using X-ray absorption fine structure spectroscopy. Geochimica et Cosmochimica Acta 73, 3260-3276.

Delaire, C., Amrose, S., Zhang, M., Hake, J. and Gadgil, A. (2017) How do operating conditions affect As(III) removal by iron electrocoagulation? Water Research 112, 185 194.

Dittmar, J., Voegelin, A., Maurer, F., Roberts, L.C., Hug, S.J., Saha, G.C., Ali, M.A., Badruzzaman, A.B.M. and Kretzschmar, R. (2010a) Arsenic in soil and irrigation water affects arsenic uptake by rice: Complementary insights from field and pot studies. Environmental Science and Technology 44, 8842-8848.

Dittmar, J., Voegelin, A., Roberts, L.C., Hug, S.J., Saha, G.C., Ali, M.A., Badruzzaman, A.B.M. and Kretzschmar, R. (2007) Spatial distribution and temporal variability of arsenic in irrigated rice fields in Bangladesh: 2. Paddy soil. Environmental Science and Technology 41, 5967-5972.

Dittmar, J., Voegelin, A., Roberts, L.C., Hug, S.J., Saha, G.C., Ali, M.A., Badruzzaman, A.B.M. and Kretzschmar, R. (2010b) Arsenic accumulation in a paddy field in Bangladesh: Seasonal dynamics and trends over a three-year monitoring period. Environmental Science and Technology 44, 2925-2931.

Dixit, S. and Hering, J.G. (2003) Comparison of arsenic(V) and arsenic(III) sorption onto iron oxide minerals: Implications for arsenic mobility. Environmental Science and Technology 37, 4182-4189.

Ford, R.G. (2002) Rates of hydrous ferric oxide crystallization and the influence on coprecipitated arsenic. Environmental Science and Technology 36, 2459-2463.

Frommer, J., Voegelin, A., Dittmar, J., Marcus, M.A. and Kretzschmar, R. (2011) Biogeochemical processes and arsenic enrichment around rice roots in paddy soil: results from micro-focused X-ray spectroscopy. European Journal of Soil Science 62, 305-317.

Fuller, C.C., Davis, J.A. and Waychunas, G.A. (1993) Surface chemistry of ferrihydrite: Part 2. Kinetics of arsenate adsorption and coprecipitation. Geochimica et Cosmochimica Acta 57, 2271-2282.

Gao, Y. and Mucci, A. (2003) Individual and competitive adsorption of phosphate and arsenate on goethite in artificial seawater. Chemical Geology 199, 91-109. 
Griffioen, J. (2006) Extent of immobilisation of phosphate during aeration of nutrient-rich, anoxic groundwater. Journal of Hydrology 320, 359-369.

Hug, S.J. and Leupin, O. (2003) Iron-catalyzed oxidation of arsenic(III) by oxygen and by hydrogen peroxide: $\mathrm{pH}$-dependent formation of oxidants in the Fenton reaction. Environmental Science and Technology 37, 2734-2742.

Hug, S.J., Leupin, O.X. and Berg, M. (2008) Bangladesh and Vietnam: Different groundwater compositions require different approaches to arsenic mitigation. Environmental Science and Technology 42, 6318-6323.

Katsoyiannis, I.A., Ruettimann, T. and Hug, S.J. (2008) pH dependence of Fenton reagent generation and $\mathrm{As}(\mathrm{III})$ oxidation and removal by corrosion of zero valent iron in aerated water. Environmental Science and Technology 42, 7424-7430.

Kinniburgh, D.G. and Cooper, D.M. (2016) PhreePlot: Creating graphical output with PHREEQC.

Lakshmanan, D., Clifford, D.A. and Samanta, G. (2009) Ferrous and ferric ion generation during iron electrocoagulation. Environmental Science and Technology 43(10), 38533859.

Leupin, O.X. and Hug, S.J. (2005) Oxidation and removal of arsenic(III) from aerated groundwater by filtration through sand and zero-valent iron. Water Research 39, 17291740.

Leupin, O.X., Hug, S.J. and Badruzzaman, A.B.M. (2005) Arsenic removal from Bangladesh tube well water with filter columns containing zerovalent iron filings and sand. Environmental Science and Technology 39(20), 8032-8037.

Li, L., van Genuchten, C.M., Addy, S.E.A., Yao, J., Gao, N. and Gadgil, A.J. (2012) Modeling As(III) oxidation and removal with iron electrocoagulation in groundwater. Environmental Science and Technology 46, 12038-12045.

Luedecke, C., Hermanowicz, S.W. and Jenkins, D. (1989) Precipitation of ferric phosphate in activated Sludge: A chemical model and its verification. Water Science and Technology 21(4-5), 325-337.

Majzlan, J., Lalinská, B., Chovan, M., Jurkovic, L., Milovská, S. and Göttlicher, J. (2007) The formation, structure, and aging of As-rich hydrous ferric oxide at the abandoned $\mathrm{Sb}$ deposit Pezinok (Slovakia). Geochimica et Cosmochimica Acta 71, 4206-4220.

Mayer, D.T. and Jarrell, W.M. (1996) Formation and stability of iron(II) oxidation products under natural concentrations of dissolved silica. Water Research 30, 1208-1214.

Mayer, D.T. and Jarrell, W.M. (2000) Phosphorus sorption during iron(II) oxidation in the presence of dissolved silica. Water Research 34, 3949-3956.

Melkonian, S., Argos, M., Hall, M.N., Chen, Y., Parvez, F., Pierce, B., Cao, H., AschebrookKilfoy, B., Ahmed, A., Islam, T., Slavcovich, V., Gamble, M., Haris, P.I., Graziano, J.H. and Ahsan, H. (2013) Urinary and dietary analysis of 18,470 bangladeshis reveal a correlation of rice consumption with arsenic exposure and toxicity. PLoS One 8(11), e80691.

Meng, X., Bang, S. and Korfiatis, G.P. (2000) Effects of silicate, sulfate, and carbonate on arsenic removal by ferric chloride. Water Research 34, 1255-1261.

Meng, X., Korfiatis, G.P., Christodoulatos, C. and Bang, S. (2001) Treatment of arsenic in Bangladesh well water using a household co-precipitation and filtration system. Water Research 35, 2805-2810. 
Meng, X.G., Korfiatis, G.P., Bang, S.B. and Bang, K.W. (2002) Combined effects of anions on arsenic removal by iron hydroxides. Toxicology Letters 133(1), 103-111.

Murcott, S. (2012) Arsenic Contamination in the World - An International Sourceboob, IWA Publishing, London.

Nikolaidis, N.P., Dobbs, G.M. and Lackovic, J.A. (2003) Arsenic removal by zero-valent iron: field, laboratory and modeling studies. Water Research 37(6), 1417-1425.

Paktunc, D., Dutrizac, J. and Gertsman, V. (2008) Synthesis and phase transformations involving scorodite, ferric arsenate and arsenical ferrihydrite: Implications for arsenic mobility. Geochimica et Cosmochimica Acta 72, 2649-2672.

Paktunc, D., Majzlan, J., Huang, A., Thibault, Y., Johnson Michel, B. and White Mary, A. (2015) Synthesis, characterization, and thermodynamics of arsenates forming in the Ca$\mathrm{Fe}(\mathrm{III})-\mathrm{As}(\mathrm{V})-\mathrm{NO}_{3}$ system: Implications for the stability of Ca-Fe arsenates, p. 1803.

Panaullah, G.M., Alam, T., Hossain, M.B., Loeppert, R.H., Lauren, J.G., Meisner, C.A., Ahmed, Z.U. and Duxbury, J.M. (2008) Arsenic toxicity to rice (Oryza sativa L.) in Bangladesh. Plant and Soil 317(1), 31.

Parkhurst, D.L. and Appelo, C.A.J. (1999) User's guide to PHREEQC (Version 2) -- a computer program for speciation, batch-reaction, one-dimensional transport, and inverse geochemical calculations, p. 312, U.S. Geological Survey, Denver, CO.

Ratna Kumar, P., Chaudhari, S., Khilar, K.C. and Mahajan, S.P. (2004) Removal of arsenic from water by electrocoagulation. Chemosphere 55(9), 1245-1252.

Roberts, L.C., Hug, S.J., Dittmar, J., Voegelin, A., Kretzschmar, R., Wehrli, B., Cirpka, O.A., Saha, G.C., Ali, M.A. and Badruzzaman, A.B.M. (2010) Arsenic release from paddy soils during monsoon flooding. Nature Geoscience 3, 53-59.

Roberts, L.C., Hug, S.J., Dittmar, J., Voegelin, A., Saha, G.C., Ali, M.A., Badruzzaman, A.B.M. and Kretzschmar, R. (2007) Spatial distribution and temporal variability of arsenic in irrigated rice fields in Bangladesh: 1. Irrigation water. Environmental Science and Technology 41, 5960-5966.

Roberts, L.C., Hug, S.J., Ruettimann, T., Billah, M.M., Khan, A.W. and Rahman, M.T. (2004) Arsenic removal with iron(II) and iron(III) in waters with high silicate and phosphate concentrations. Environmental Science and Technology 38, 307-315.

Senn, A.-C., Kaegi, R., Hug, S.J., Hering, J.G., Mangold, S. and Voegelin, A. (2015) Composition and structure of $\mathrm{Fe}$ (III)-precipitates formed by $\mathrm{Fe}(\mathrm{II})$ oxidation in nearneutral water: Interdependent effects of phosphate, silicate and Ca. Geochimica et Cosmochimica Acta 162, 220-246.

Senn, A.-C., Kaegi, R., Hug, S.J., Hering, J.G. and Voegelin, A. (2017) Effect of aging on the structure and phosphate retention of $\mathrm{Fe}(\mathrm{III})$-precipitates formed by $\mathrm{Fe}(\mathrm{II})$ oxidation in water. Geochimica et Cosmochimica Acta 202, 341-360.

Smedley, P.L. and Kinniburgh, D.G. (2002) A review of the source, behaviour and distribution of arsenic in natural waters. Applied Geochemistry 17, 517-568.

Stumm, W., Morgan, J.J. and Black, A.P. (1962) Chemical Aspects of Coagulation [with Discussion]. Journal (American Water Works Association) 54(8), 971-994.

Su, C. and Puls, R.W. (2001a) Arsenate and arsenite removal by zerovalent iron: Effects of phosphate, silicate, carbonate, borate, sulfate, chromate, molybdate, and nitrate, relative to chloride. Environmental Science and Technology 35, 4562-4568. 
Su, C. and Puls, R.W. (2001b) Arsenate and arsenite removal by zerovalent iron: Kinetics, redox transformation, and implications for in situ groundwater remediation. Environmental Science and Technology 35, 1487-1492.

Tessenow, U. (1974) Lösungs-, Diffusions- und Sorptionsprozesse in der Oberschicht von Seesedimenten. IV. Reaktionsmechanismen und Gleichgewichte im System EisenMangan-Phosphat im Hinblick auf die Vivianitakkumulation im Ursee. Archiv für Hydrobiologie Supplement 47, 1-79.

van der Grift, B., Behrends, T., Osté, L.A., Schot, P.P., Wassen, M.J. and Griffioen, J. (2016) Fe hydroxyphosphate precipitation and $\mathrm{Fe}(\mathrm{II})$ oxidation kinetics upton aeration of $\mathrm{Fe}(\mathrm{II})$ and phosphate-containing synthetic and natural solutions. Geochimica et Cosmochimica Acta 186, 71-90.

van Genuchten, C.M., Addy, S.E.A., Pena, J. and Gadgil, A.J. (2012) Removing arsenic from synthetic groundwater with iron electrocoagulation: An Fe and As K-edge EXAFS study. Environmental Science and Technology 46, 986-994.

van Genuchten, C.M., Gadgil, A.J. and Peña, J. (2014a) Fe(III) nucleation in the presence of bivalent cations and oxyanions leads to subnanoscale $7 \AA$ polymers. Environmental Science and Technology 48, 11828-11836.

van Genuchten, C.M., Peña, J., Amrose, S.E. and Gadgil, A.J. (2014b) Structure of Fe(III) precipitates generated by the electrolytic dissolution of $\mathrm{Fe}(0)$ in the presence of groundwater ions. Geochimica et Cosmochimica Acta 127, 285-304.

Violante, A., Del Gaudio, S., Pigna, M., Ricciardella, M. and Banerjee, D. (2007) Coprecipitation of arsenate with metal oxides. 2. Nature, mineralogy, and reactivity of iron(III) precipitates. Environmental Science and Technology 41, 8275-8280.

Voegelin, A., Kaegi, R., Frommer, J., Vantelon, D. and Hug, S.J. (2010) Effect of phosphate, silicate, and $\mathrm{Ca}$ on $\mathrm{Fe}(\mathrm{III})$-precipitates formed in aerated $\mathrm{Fe}(\mathrm{II})$ - and $\mathrm{As}(\mathrm{III})$-containing water studied by X-ray absorption spectroscopy. Geochimica et Cosmochimica Acta 74, 164-186.

Voegelin, A., Senn, A.-C., Kaegi, R., Hug, S.J. and Mangold, S. (2013) Dynamic Feprecipitate formation induced by $\mathrm{Fe}(\mathrm{II})$ oxidation in aerated phosphate-containing water. Geochimica et Cosmochimica Acta 117, 216-231.

Waychunas, G.A., Rea, B.A., Fuller, C.C. and Davis, J.A. (1993) Surface chemistry of ferrihydrite: Part 1. EXAFS studies of the geometry of coprecipitated and adsorbed arsenate. Geochimica et Cosmochimica Acta 57, 2251-2269.

Weber, F.-A., Hofacker, A., Voegelin, A. and Kretzschmar, R. (2010) Temperature dependence and coupling of iron and arsenic reduction and release during flooding of a contaminated soil. Environmental Science and Technology 44, 116-122.

Wilkie, J.A. and Hering, J.G. (1996) Adsorption of arsenic onto hydrous ferric oxide: Effects of adsorbate/adsorbent ratios and co-occurring solutes. Colloids and Surfaces A:Physicochemical and Engineering Aspects 107, 97-110. 
688 Table 1. Overview over the formation and structure of fresh $\mathrm{Fe}(\mathrm{III})$-precipitates in $\mathrm{Na}$, $689 \mathrm{Na}+\mathrm{Si}, \mathrm{Ca}$, and $\mathrm{Ca}+\mathrm{Si}$ electrolytes and corresponding critical $\mathrm{P} / \mathrm{Fe}\left((\mathrm{P} / \mathrm{Fe})_{\text {crit }}\right)^{\mathrm{a}}$ (Senn et al. 690 2015) and over changes in precipitate structure after aging for $30 \mathrm{~d}$ at $40{ }^{\circ} \mathrm{C}$ (Senn et al. 691 2017).

\begin{tabular}{|c|c|c|c|c|}
\hline \multicolumn{5}{|c|}{ Structure of fresh precipitates } \\
\hline Electrolyte & $(\mathbf{P} / \mathbf{F e})_{\text {crit }^{a}}$ & \multicolumn{2}{|l|}{ above $(\mathbf{P} / \mathbf{F e})_{\text {crit }}$} & below $(\mathbf{P} / \mathbf{F e})_{\text {crit }}$ \\
\hline general & & \multicolumn{2}{|c|}{$\begin{array}{l}\text { - exclusive precipitation of } \\
\text { (Ca-)Fe(III)-phosphate } \\
\text { - structural effect of } \mathrm{Ca}\end{array}$} & $\begin{array}{l}\text { - sequential precipitate formation, } \\
\text { - first (Ca-)Fe(III)-phosphate until P } \\
\text { depletion } \\
\text { - subsequently structural effect of Si }\end{array}$ \\
\hline $\mathbf{N a}$ & $0.52 \pm 0.01$ & \multicolumn{2}{|l|}{ - Fe(III)-phosphate } & $\begin{array}{l}\text { - Fe(III)-phosphate (readily transforming) } \\
\text { - P-rich ferrihydrite } \\
\text { - poorly-crystalline lepidocrocite }\end{array}$ \\
\hline $\mathbf{N a}+\mathbf{S i}$ & $0.53 \pm 0.01$ & \multicolumn{2}{|l|}{ - Fe(III)-phosphate } & $\begin{array}{l}\text { - Fe(III)-phosphate (transforming) } \\
\text { - Si-rich ferrihydrite }\end{array}$ \\
\hline $\mathbf{C a}$ & $0.85 \pm 0.03$ & \multicolumn{2}{|l|}{ - Ca-Fe(III)-phosphate } & $\begin{array}{l}\text { - Ca-Fe(III)-phosphate (Ca-stabilized) } \\
\text { - P-rich ferrihydrite } \\
\text { - poorly-crystalline lepidocrocite }\end{array}$ \\
\hline $\mathbf{C a}+\mathbf{S i}$ & $0.87 \pm 0.03$ & \multicolumn{2}{|l|}{ - Ca-Fe(III)-phosphate } & $\begin{array}{l}\text { - Ca-Fe(III)-phosphate (Ca-stabilized) } \\
\text { - Si-rich ferrihydrite }\end{array}$ \\
\hline \multicolumn{5}{|c|}{ Effects of aging on precipitate structure } \\
\hline Electrolyte & \multicolumn{2}{|c|}{ above $(\mathrm{P} / \mathrm{Fe})_{\text {init }}>0.75$} & & below $(\mathrm{P} / \mathrm{Fe})_{\text {init }}<0.75$ \\
\hline general & \multicolumn{2}{|c|}{$\begin{array}{l}\text { - transformation inhibited by } \\
\text { dissolved } \mathrm{P} \text { and structural } \mathrm{Ca}\end{array}$} & \multicolumn{2}{|c|}{$\begin{array}{l}\text { - transformation of (Ca-)Fe(III)-phosphate } \\
\text { - Ca inhibits Ca-Fe(III)-phosphate transformation } \\
\text { - Si inhibits ferrihydrite transformation }\end{array}$} \\
\hline $\mathbf{N a}$ & \multicolumn{2}{|c|}{ - Fe(III)-phosphate } & \multicolumn{2}{|c|}{$\begin{array}{l}\text { - Fe(III)-phosphate (residual) } \\
\text { - P-rich ferrihydrite (from Fe(III)-phosphate) } \\
\text { - poorly-crystalline lepidocrocite }\end{array}$} \\
\hline $\mathbf{N a}+\mathbf{S i}$ & \multicolumn{2}{|c|}{ - Fe(III)-phosphate } & \multicolumn{2}{|c|}{$\begin{array}{l}\text { - Fe(III)-phosphate (residual) } \\
\text { - Si- and P-containing ferrihydrite }\end{array}$} \\
\hline $\mathbf{C a}$ & \multicolumn{2}{|c|}{ - Ca-Fe(III)-phosphate } & \multicolumn{2}{|c|}{$\begin{array}{l}\text { - Ca-Fe(III)-phosphate (Ca-stabilized }) \\
\text { - (P-rich ferrihydrite from Ca-Fe(III)-phosphate) } \\
\text { - poorly crystalline lepidocrocite }\end{array}$} \\
\hline $\mathbf{C a}+\mathbf{S i}$ & \multicolumn{2}{|c|}{ - Ca-Fe(III)-phosphate } & \multicolumn{2}{|c|}{$\begin{array}{l}\text { - Ca-Fe(III)-phosphate (Ca-stabilized) } \\
\text { - Si-rich ferrihydrite-type precipitate }\end{array}$} \\
\hline
\end{tabular}

${ }^{\mathrm{a}}$ The critical $\mathrm{P} / \mathrm{Fe}\left((\mathrm{P} / \mathrm{Fe})_{\text {crit }}\right)$ refers to the initial dissolved $\mathrm{P} / \mathrm{Fe}$ ratio $((\mathrm{P} / \mathrm{Fe})$ init $)$ above which exclusive formation of amorphous (Ca-)Fe(III)-phosphate occurs. At $(\mathrm{P} / \mathrm{Fe})_{\text {init }} \sim(\mathrm{P} / \mathrm{Fe})_{\text {crit }}$, the molar $\mathrm{P} / \mathrm{Fe}$ ratio of the $\mathrm{Fe}(\mathrm{III})$-precipitate $\left((\mathrm{P} / \mathrm{Fe})_{\mathrm{ppt}}\right)$ corresponds to $\sim(\mathrm{P} / \mathrm{Fe})_{\text {init. }}$. Senn et al. 2015). 
Table 2. Parameters of competitive co-precipitation model. ${ }^{\mathrm{a}}$

\begin{tabular}{|c|c|c|c|c|c|}
\hline Electrolyte / Study & $S$ & $\log K_{\text {As }}$ & $\log K_{P}$ & $\log K_{S i}$ & SSR \\
\hline $\mathrm{Na} / \mathrm{Na}+\mathrm{Si}$ & $0.58(0.02)$ & $5.34(0.12)$ & $5.45(0.12)$ & $2.46(0.19)$ & \multirow{3}{*}{0.055} \\
\hline $\mathrm{Mg} / \mathrm{low} \mathrm{Ca}$ & $0.72(0.02)$ & $5.34(0.14)$ & $5.40(0.13)$ & --- & \\
\hline $\mathrm{Ca} / \mathrm{Ca}+\mathrm{Si}$ & $1.02(0.02)$ & $5.09(0.10)$ & $5.42(0.10)$ & $2.40(0.11)$ & \\
\hline All electrolytes & $0.78(0.03)$ & $5.09(0.12)$ & $5.26(0.12)$ & $2.41(0.22)$ & 0.279 \\
\hline Roberts et al. (2004) & $0.72(0.06)$ & $5.72(0.23)$ & $5.87(0.15)$ & $2.77(0.08)$ & --- \\
\hline
\end{tabular}

$698{ }^{\mathrm{a}}$ Fit parameters obtained by non-linear least-squares minimization of the sum of the squared 699 residuals between modelled and measured concentrations of $\mathrm{As}(\mathrm{V})$ (weighed by factor 100),

$700 \mathrm{P}$ and $\mathrm{Si}$ in indicated electrolytes. For the Si-free electrolytes, the 5 datapoints from $(\mathrm{P} / \mathrm{Fe})_{\text {init }}$ 701 of 0 to 0.3 were not included, as the model does not account for $\mathrm{As}(\mathrm{V})$ and $\mathrm{P}$ release due to 702 continuing precipitate polymerization. S represents the site concentration in mole sites per 703 mole $\mathrm{Fe}, \mathrm{K}_{\mathrm{X}}$ represent the sorption coefficients for oxyanion X. Values in parentheses 704 indicate the estimated standard error.

$705{ }^{b}$ Fit parameters from Roberts et al. (2004) for Fe(III)-precipitates formed by oxidation of 706 spiked Fe(II) (from fit with unconstrained parameters for As(III) co-oxidation; note that no 707 As(III) was used in current study).

$708{ }^{\mathrm{c}} \mathrm{SSR}=$ sum of squared residuals; Sum of SSR for $\mathrm{Na} / \mathrm{Na}+\mathrm{Si}, \mathrm{Ca} / \mathrm{Ca}+\mathrm{Si}$ and $\mathrm{Mg} / \mathrm{low} \mathrm{Ca}$ 709 electrolytes (0.055) about 5 times lower than SSR of fit over all electrolytes. 
arsenate
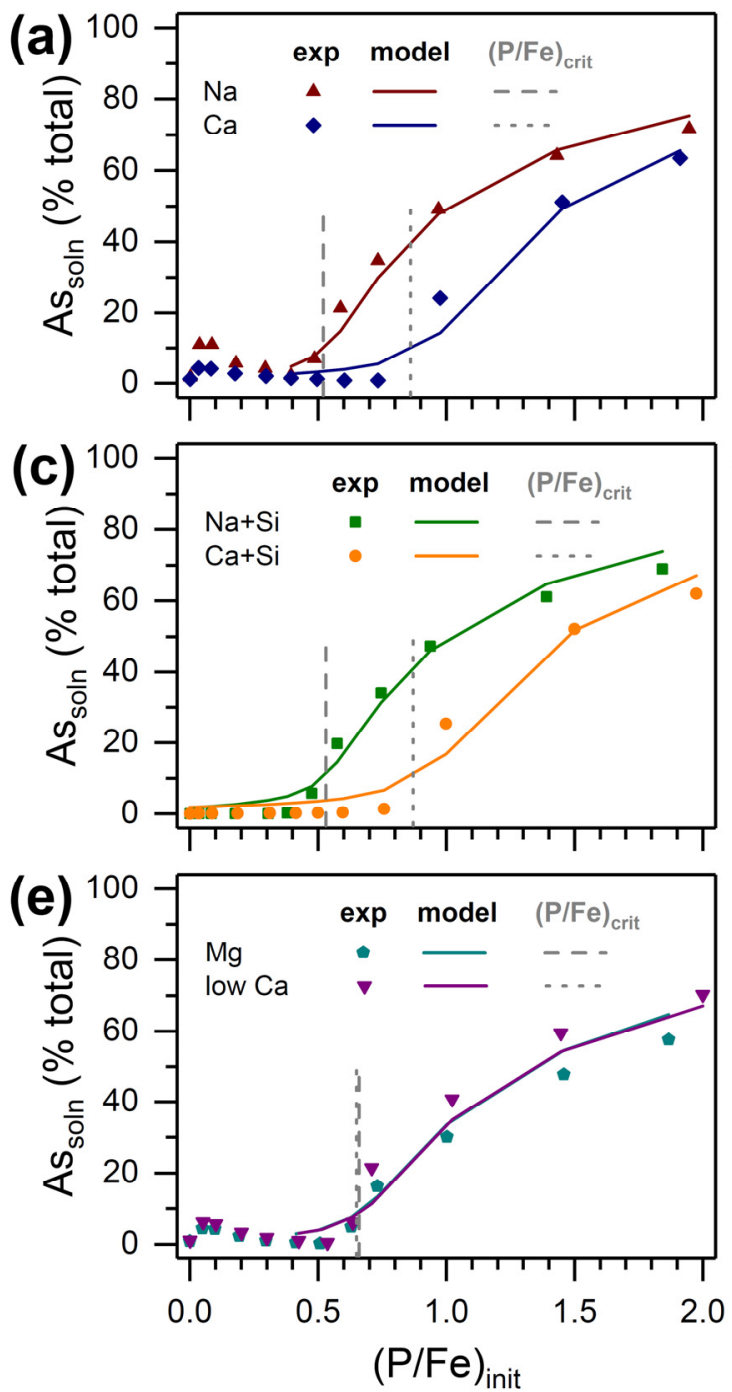

phosphate
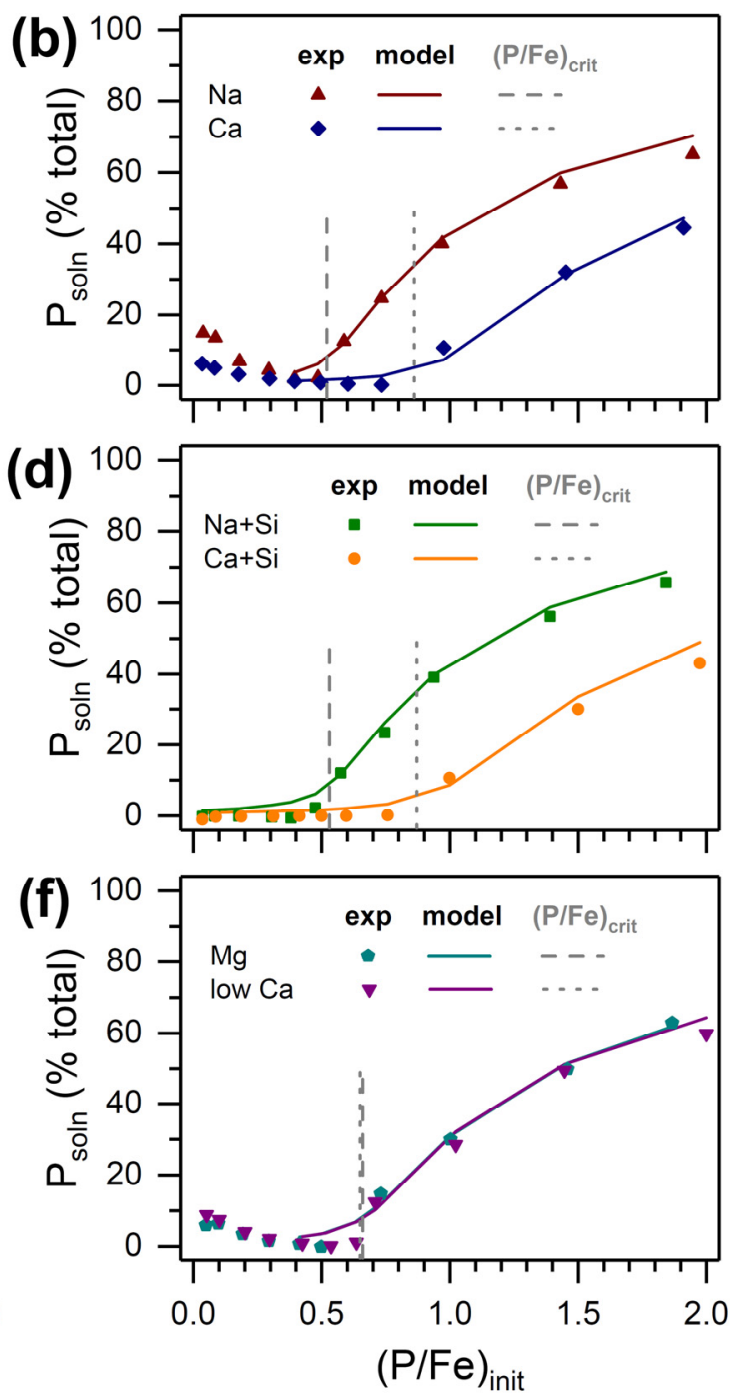

712 Figure 1. Dissolved As (a,c,e) and $\mathrm{P}(\mathrm{b}, \mathrm{d}, \mathrm{f})$ fractions in fresh suspensions in percent of 713 initially spiked amounts as a function of $(\mathrm{P} / \mathrm{Fe})_{\text {init }}$ in $\mathrm{Na}, \mathrm{Ca}, \mathrm{Na}+\mathrm{Si}, \mathrm{Ca}+\mathrm{Si}$, low $\mathrm{Ca}$ and $\mathrm{Mg}$ 714 background electrolytes. Thin vertical lines indicate the $(\mathrm{P} / \mathrm{Fe})$ crit of the respective 715 electrolytes (from Senn et al. (2015)). Solid lines represent model calculations based on 716 parameters optimized separately for the $\mathrm{Na} / \mathrm{Na}+\mathrm{Si}$, the $\mathrm{Ca} / \mathrm{Ca}+\mathrm{Si}$, and the $\mathrm{Mg} / \mathrm{low} \mathrm{Ca}$ 717 electrolytes (Table 2). Data for dissolved P from Senn et al. (2015). 


\section{fresh}
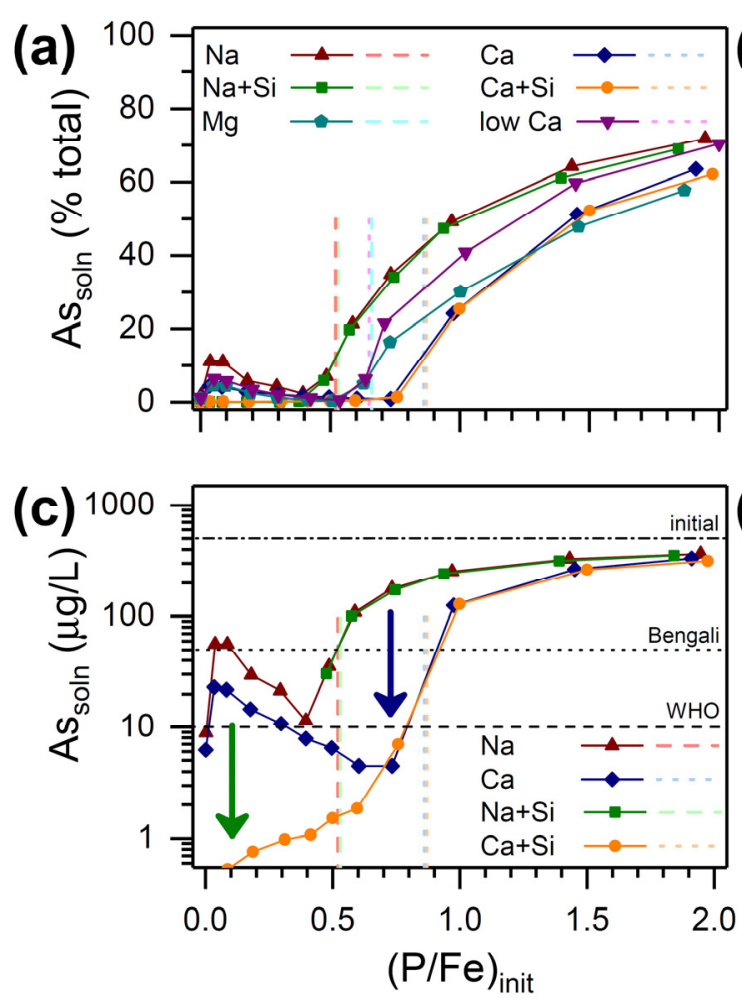

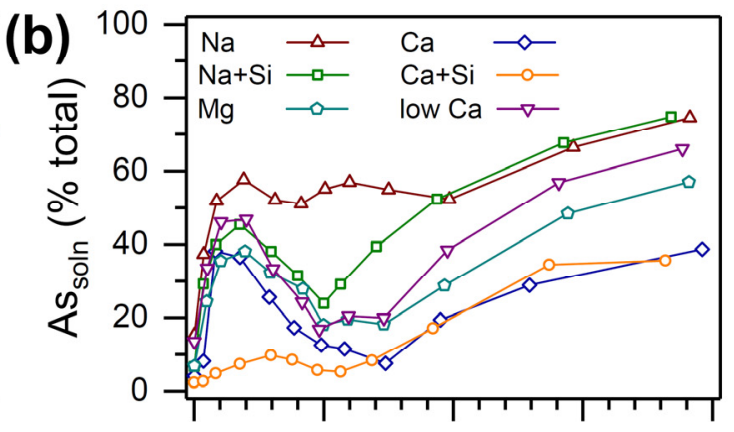

aged

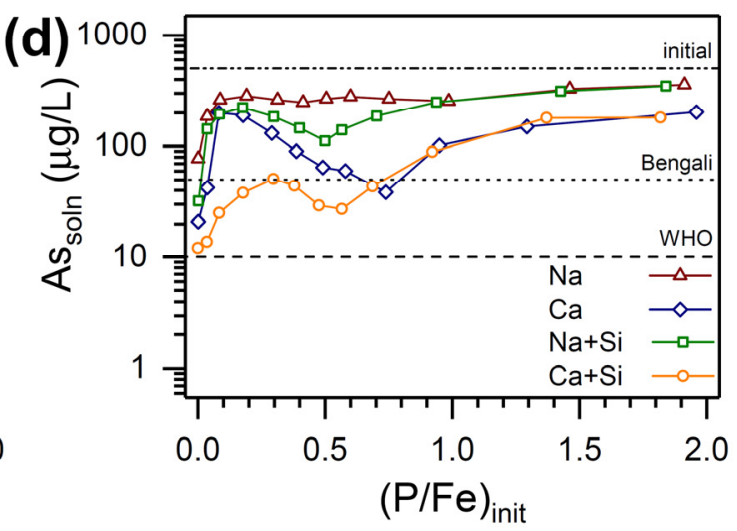

Figure 2. Dissolved As(V) in fresh $(\mathrm{a}, \mathrm{c})$ and aged $(\mathrm{b}, \mathrm{d})$ suspensions as a function of $(\mathrm{P} / \mathrm{Fe})_{\text {init; }}$;

720 in percent of initially spiked amounts on linear scale (a, b; all electrolytes) and in absolute concentration units $(\mu \mathrm{g} / \mathrm{L})$ on a logarithmic scale (c, d; $\mathrm{Na}, \mathrm{Ca}, \mathrm{Na}+\mathrm{Si}$ and $\mathrm{Ca}+\mathrm{Si}$ electrolytes). Horizontal lines in (c, d) mark the initial total As(V) concentration (dash-dot), $50 \mu \mathrm{g} / \mathrm{L}$ (dot; Bengali drinking water limit) and $10 \mu \mathrm{g} / \mathrm{L}$ (dash; WHO drinking water limit). Thin vertical lines in $(\mathrm{a}, \mathrm{c})$ indicate the $(\mathrm{P} / \mathrm{Fe})_{\text {crit }}$ of the individual electrolytes (from Senn et al. (2015)). The arrows in panel (c) indicate the marked effects of Si (green) and Ca (blue) on residual dissolved As concentrations in the fresh suspensions. 

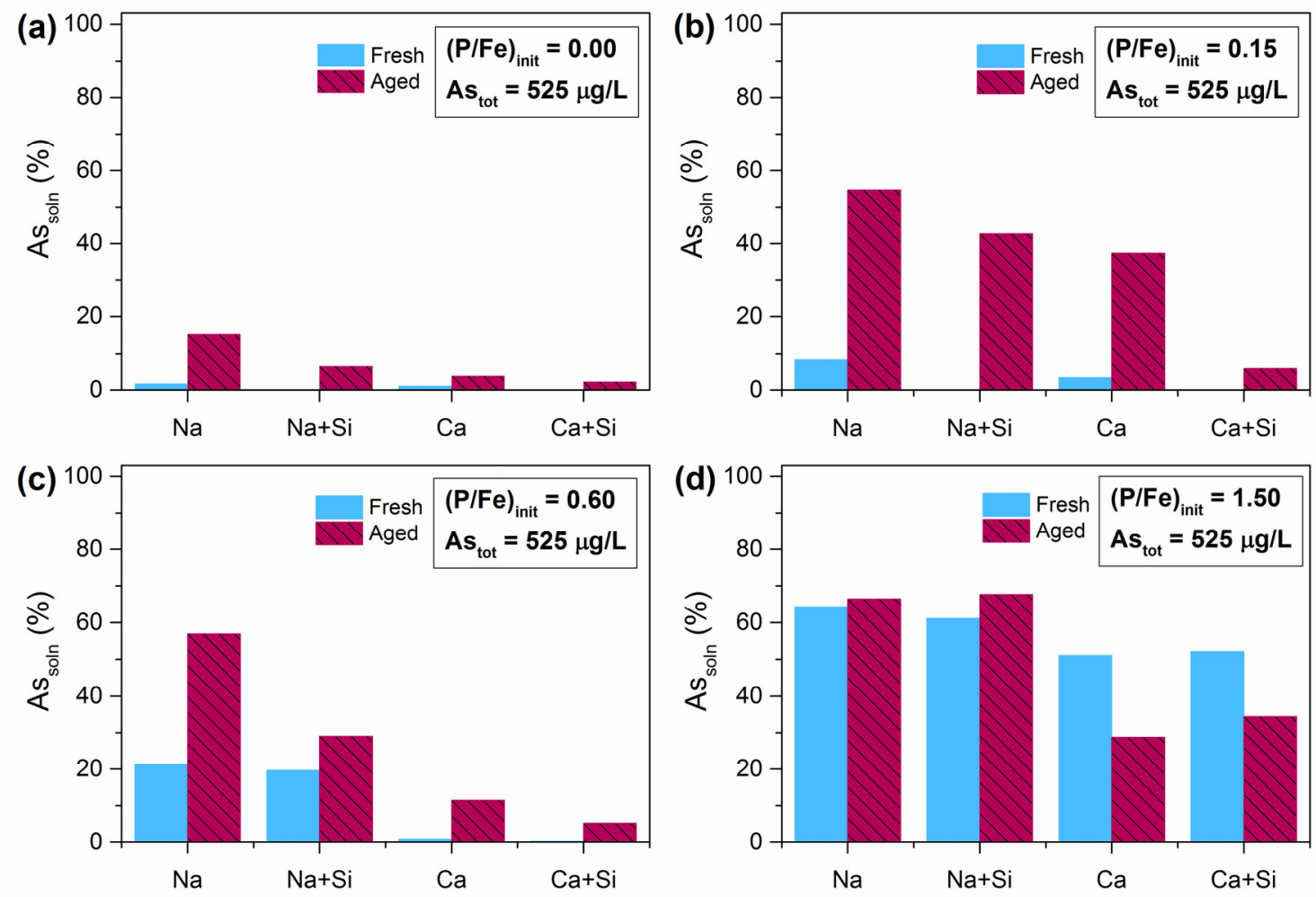

731 Figure 3. Dissolved total $\mathrm{As}\left(\mathrm{As}_{\mathrm{soln}}\right)(\%$ of total initial $\mathrm{As}(\mathrm{V}))$ in fresh and aged precipitate 732 suspensions at (nominal) $(\mathrm{P} / \mathrm{Fe})_{\text {init }}$ of $0.00,0.15,0.60$ and 1.50 in $\mathrm{Na}, \mathrm{Na}+\mathrm{Si}, \mathrm{Ca}$, and $\mathrm{Ca}+\mathrm{Si}$ 733 background electrolyte. Values at $(\mathrm{P} / \mathrm{Fe})_{\text {init }} 0.15$ are an average of data from $(\mathrm{P} / \mathrm{Fe})_{\text {init }} 0.10$ and 0.20 . 


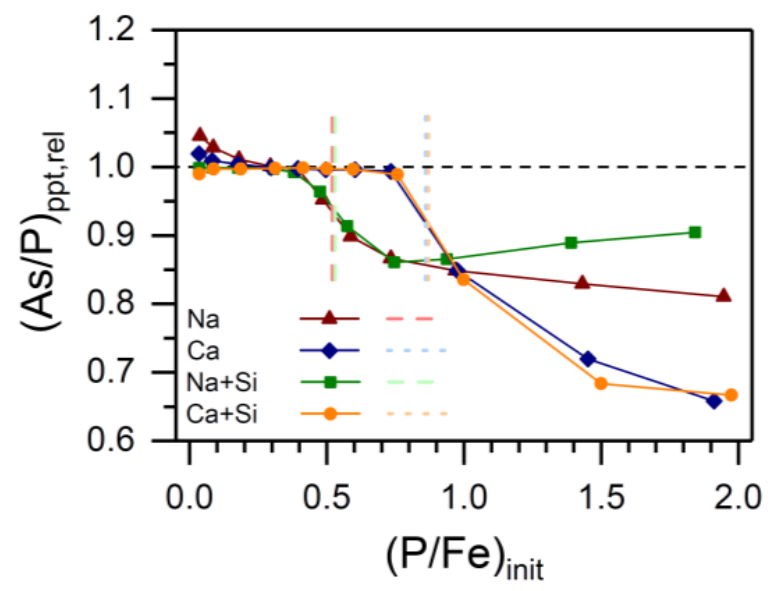

737 Figure 4. Relative precipitate $\mathrm{As} / \mathrm{P}$ ratio $(\mathrm{As} / \mathrm{P})_{\mathrm{ppt}, \mathrm{rel}}$ in the $\mathrm{Na}, \mathrm{Ca}, \mathrm{Na}+\mathrm{Si}$ and $\mathrm{Ca}+\mathrm{Si}$ 738 electrolytes as a function of $(\mathrm{P} / \mathrm{Fe})_{\text {init. }}$ The $(\mathrm{As} / \mathrm{P})_{\mathrm{ppt}, \mathrm{rel}}$ corresponds to the ratio between the 739 molar $(\mathrm{As} / \mathrm{P})_{\mathrm{ppt}}$ and the initial molar As/P ratio in solution $\left((\mathrm{As} / \mathrm{P})_{\text {init }}\right)$. Values $>1$ indicate 740 preferential uptake of $\mathrm{As}(\mathrm{V})$ over $\mathrm{P}$, values $<1$ suggest preferential uptake of $\mathrm{P}$. The thin 741 vertical lines indicate the $(\mathrm{P} / \mathrm{Fe})_{\text {crit }}$ of the different electrolytes (from Senn et al. (2015)). 
arsenate
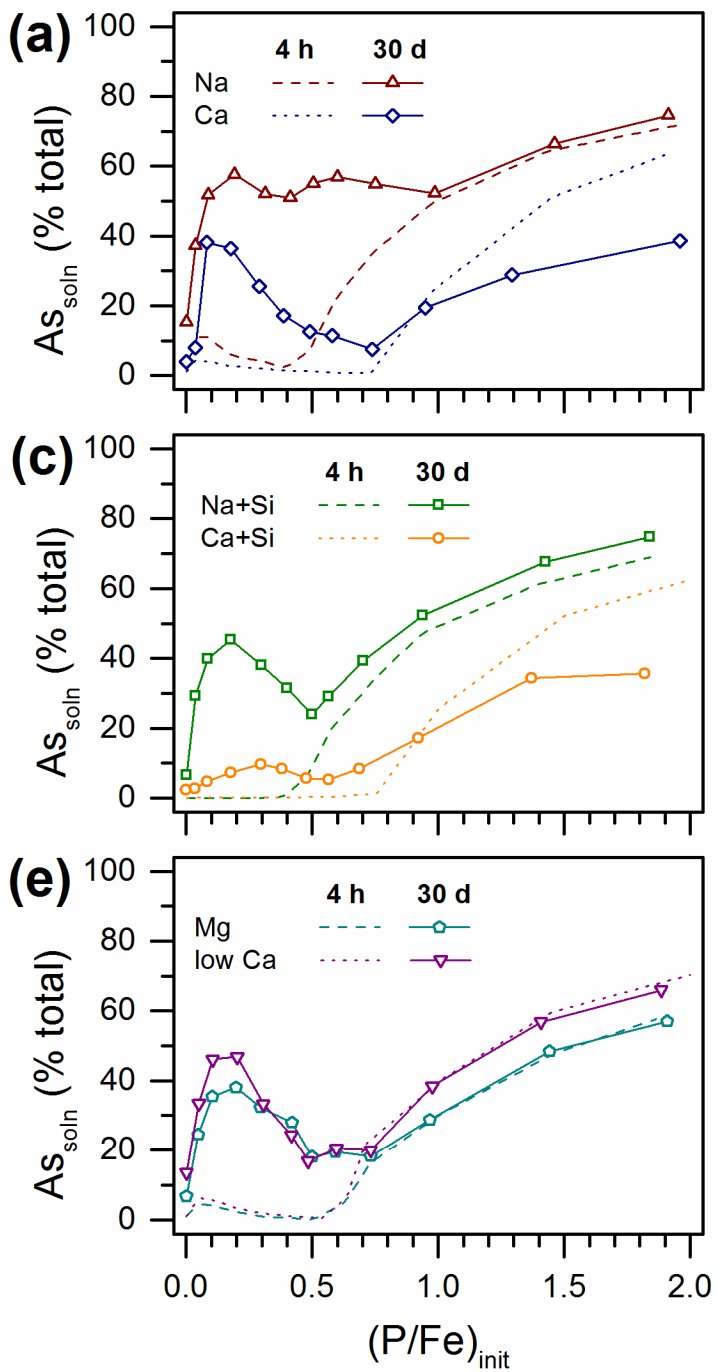

phosphate
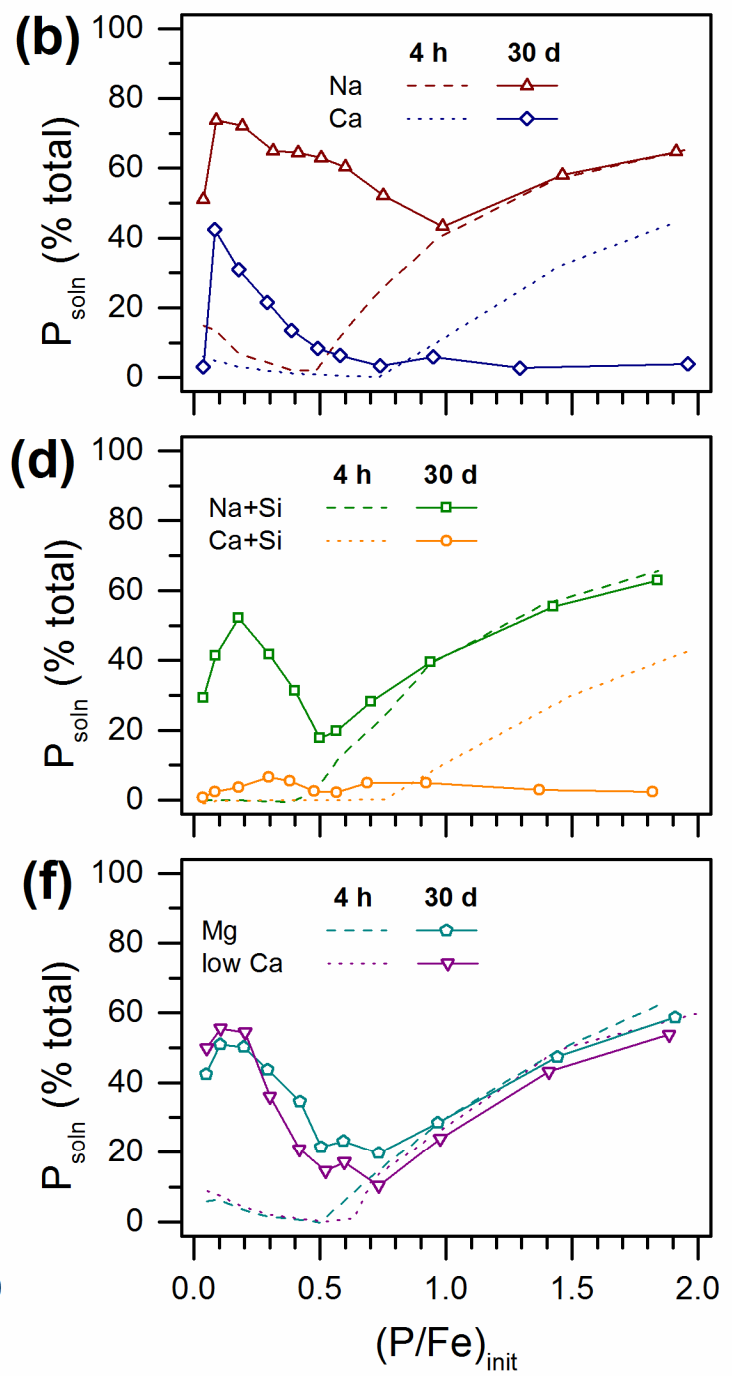
745 Figure 5. Dissolved $\mathrm{As}(\mathrm{a}, \mathrm{c}, \mathrm{e})$ and $\mathrm{P}(\mathrm{b}, \mathrm{d}, \mathrm{f})$ fractions in aged suspensions in percent of
746 initially spiked amounts as a function of $(\mathrm{P} / \mathrm{Fe})_{\text {init }}$ in $\mathrm{Na}, \mathrm{Ca}, \mathrm{Na}+\mathrm{Si}, \mathrm{Ca}+\mathrm{Si}$, low $\mathrm{Ca}$ and $\mathrm{Mg}$ 747 background electrolytes (symbols and solid lines). The corresponding concentrations in fresh 748 suspensions from Figure 2 are shown for comparison (dotted lines). Data for dissolved $\mathrm{P}$ from Senn et al. (2015) and Senn et al. (2017). 

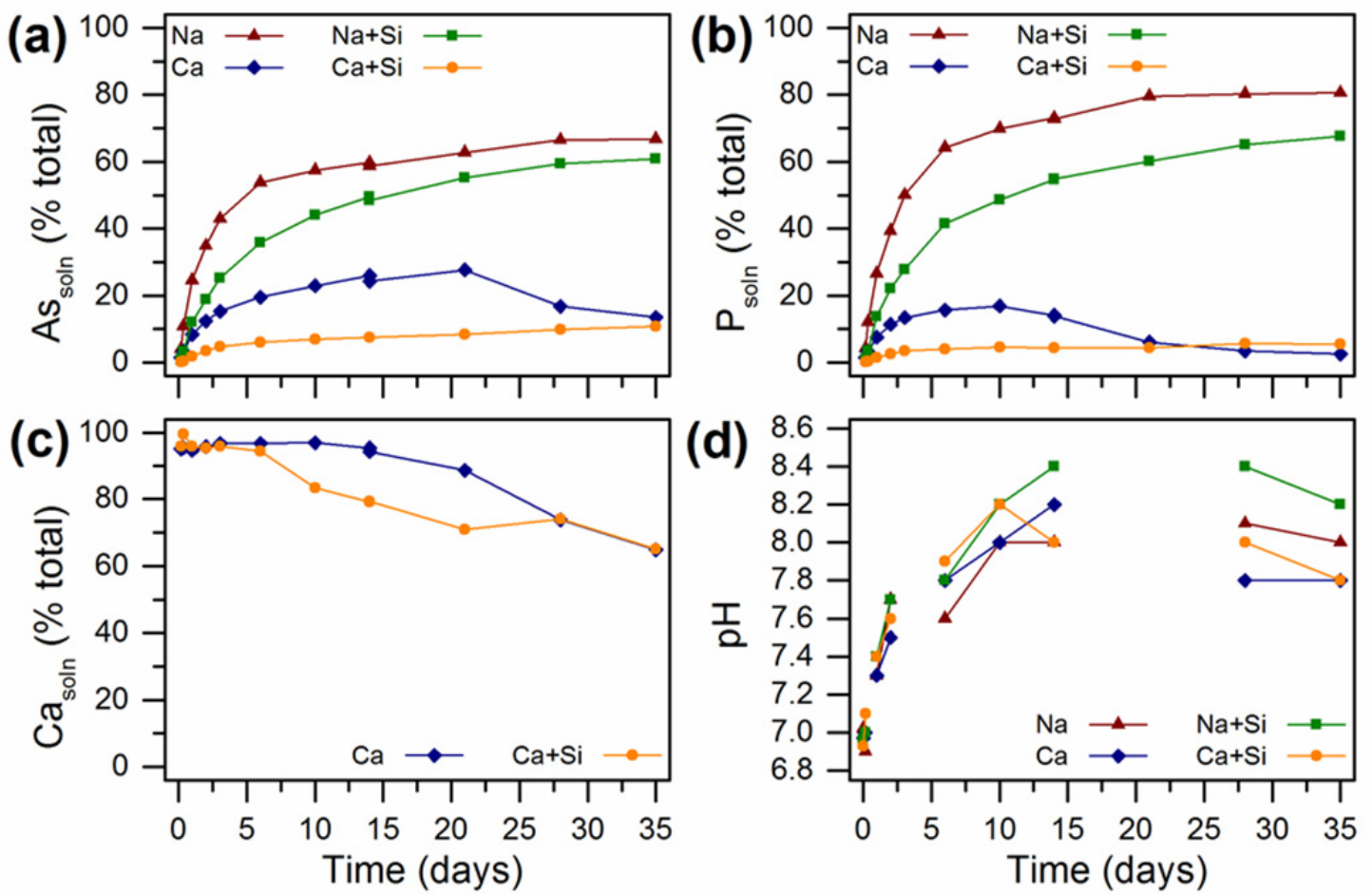

752

753

754

755

756

Figure 6. Time-resolved aging experiment at $(\mathrm{P} / \mathrm{Fe})_{\text {init }}$ of $0.25\left(\mathrm{Fe}_{\text {tot }} 0.56 \mathrm{mM}\right)$ in $\mathrm{Na}, \mathrm{Na}+\mathrm{Si}$, $\mathrm{Ca}$, and $\mathrm{Ca}+\mathrm{Si}$ electrolyte. Fractions of dissolved $\mathrm{As}(\mathrm{V})(\mathrm{a})$, dissolved $\mathrm{P}(\mathrm{b})$ and dissolved $\mathrm{Ca}$ (c) and solution $\mathrm{pH}(\mathrm{d})$. 
arsenic

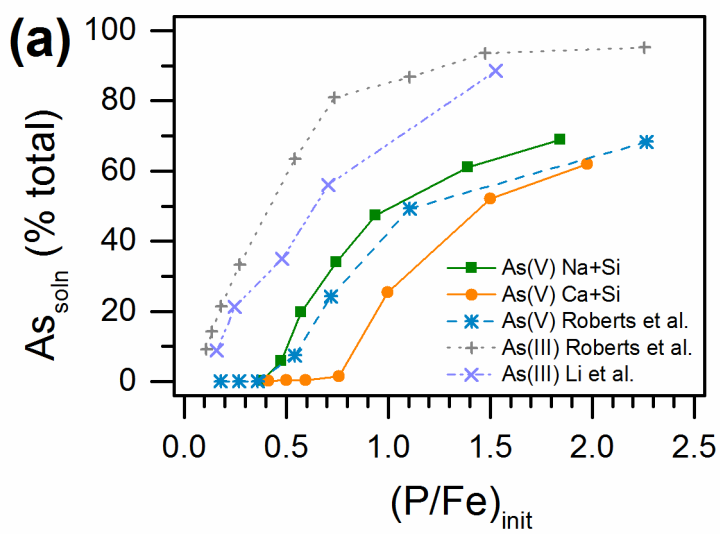

phosphate

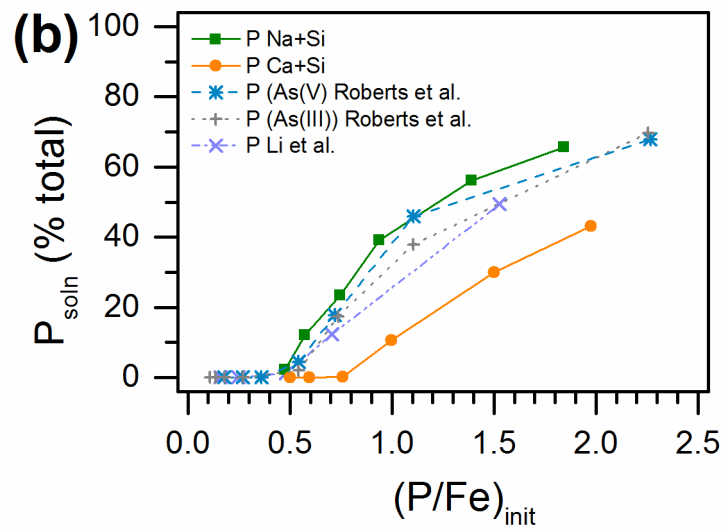

Figure 7. Data for residual dissolved $\mathrm{As}$ and $\mathrm{P}$ as a function of $(\mathrm{P} / \mathrm{Fe})_{\text {init }}$ from co-precipitation experiments in synthetic Bangladesh groundwater (SBGW) from Roberts et al. (2004) (6.7 $\mu \mathrm{M}$ As(V) or As(III), $1.07 \mathrm{mM} \mathrm{Si}, 97 \mu \mathrm{M}$ P, $2.5 \mathrm{mM} \mathrm{Ca}, 1.5 \mathrm{mM} \mathrm{Mg}$, Fe(II) from 50 to 0.04 $\mathrm{mM}, \mathrm{pH}$ 7.0) and from electrocoagulation experiments with $\mathrm{As}(\mathrm{III})$ in SBGW from Li et al. (2012) $(6.7 \mu \mathrm{M}$ As(III), $1.07 \mathrm{mM} \mathrm{Si}, 97 \mu \mathrm{M}$ P, $2.5 \mathrm{mM} \mathrm{CaCl}, 1.6 \mathrm{mM} \mathrm{MgCl} 2,8.2 \mathrm{mM}$ $\left.\mathrm{NaHCO}_{3}\right)$ in comparison to the data for $\mathrm{As}(\mathrm{V})$ and $\mathrm{P}$ in the fresh $\mathrm{Na}+\mathrm{Si}$ and $\mathrm{Ca}+\mathrm{Si}$ electrolytes (from Figure 2). Note that residual dissolved As corresponds to a mixture of $\mathrm{As}(\mathrm{III})$ and $\mathrm{As}(\mathrm{V})$ in experiments with $\mathrm{As}(\mathrm{III})$, and to $\mathrm{As}(\mathrm{V})$ in experiments with $\mathrm{As}(\mathrm{V})$. 
Supplementary Data

\title{
Arsenate co-precipitation with Fe(II) oxidation products and retention or release during precipitate aging
}

\author{
Anna-Caterina Senn ${ }^{a, b}$, Stephan J. Hug ${ }^{a}$, Ralf Kaegi ${ }^{a}$, Janet G. Hering ${ }^{a, b, c}$, Andreas Voegelin ${ }^{a, *}$ \\ ${ }^{a}$ Eawag, Swiss Federal Institute of Aquatic Science and Technology, Ueberlandstrasse 133, CH- \\ 8600 Duebendorf, Switzerland \\ ${ }^{\mathrm{b}}$ Department of Environmental Sciences, Institute of Biogeochemistry and Pollutant Dynamics, \\ ETH, Swiss Federal Institute of Technology, Zurich, Switzerland \\ ${ }^{c}$ School of Architecture Civil and Environmental Engineering, EPFL, École Polytechnique \\ Féderale de Lausanne, Switzerland \\ ${ }^{*}$ Corresponding author. E-mail address: andreas.voegelin@eawag.ch, phone +41 587655470 , \\ fax +41587655210
}

(5 pages, 1 table, 2 figures) 


\section{Solution composition in co-precipitation experiments}

Table S1. Conditions of co-precipitation experiments used for parameter optimization in our study and in Roberts et al. (2004).

\begin{tabular}{|c|c|c|c|c|}
\hline & \multicolumn{3}{|c|}{ This study } & \multirow{2}{*}{$\begin{array}{c}\text { Roberts et al., } 2004 \\
\text { SBGW }^{\mathrm{a}}\end{array}$} \\
\hline & $\mathbf{N a} / \mathbf{N a}+\mathbf{S i}$ & $\mathbf{C a} / \mathbf{C a}+\mathbf{S i}$ & $\mathrm{Mg} /$ low Ca & \\
\hline $\mathrm{pH}_{\text {init }}$ & $7.0 \pm 0.1$ & $7.0 \pm 0.1$ & $7.0 \pm 0.1$ & $7.0 \pm 0.1$ \\
\hline $\mathrm{HCO}_{3}^{-\mathrm{b}}$ & 8 & 8 & 8 & 8 \\
\hline $\mathrm{Na}^{\mathrm{c}}$ & 8 & --- & $---/ 7$ & --- \\
\hline $\mathrm{Ca}(\mathrm{mM})$ & --- & 4 & $---/ 0.5$ & 2.5 \\
\hline $\operatorname{Mg}(\mathrm{mM})$ & -- & -- & $4 /$--- & 1.6 \\
\hline Si (mM) & $---/ 0.5$ & $---/ 0.5$ & --- & 1.07 \\
\hline$P(\mathbf{m M})$ & $0.2 / 0-1^{c}$ & $0.2 / 0-1^{c}$ & $0.2-1^{c}$ & 0.097 \\
\hline $\operatorname{As}(\mu \mathrm{M})$ & 7 & 7 & 7 & 6.67 \\
\hline $\mathrm{Fe}(\mathrm{mM})$ & 0.5 & 0.5 & 0.5 & $0.04-0.9$ \\
\hline$(\mathrm{P} / \mathrm{Fe})_{\text {init }}{ }^{\mathrm{d}}$ & $0.4 / 0-2^{c}$ & $0.4 / 0-2^{c}$ & $0.4-2^{c}$ & $0.11-2.38$ \\
\hline$(\mathrm{As}(\mathrm{V}) / \mathrm{Fe})_{\text {init }}$ & 0.014 & 0.014 & 0.014 & $0.01-0.16$ \\
\hline$(\mathrm{Si} / \mathrm{Fe})_{\text {init }}$ & $---/ 1$ & $---/ 1$ & --- & $2-25$ \\
\hline$(\mathrm{Ca} / \mathbf{F e})_{\text {init }}$ & --- & 8 & $---/ 1$ & $4.7-58.6$ \\
\hline
\end{tabular}

${ }^{a}$ Synthetic Bangladesh groundwater.

${ }^{\mathrm{b}}$ Based on thermodynamic calculations, adjustment of the $\mathrm{pH}$ to 7.0 required equilibration with 38 mbar $\mathrm{CO}_{2}$ and resulted in $9.5 \mathrm{mM}$ total bicarbonate.

${ }^{\mathrm{c}} \mathrm{Na}$ added as $\mathrm{NaHCO}_{3}$. Spiking with $0.5 \mathrm{mM} \mathrm{Si}$ (as $\mathrm{Na}_{2} \mathrm{SiO}_{3} \times 9 \mathrm{H}_{2} \mathrm{O}$ ) and up to $1 \mathrm{mM} \mathrm{P}$ (as $\mathrm{NaH}_{2} \mathrm{PO}_{4} \cdot \mathrm{H}_{2} \mathrm{O}$ ), resulted in further $\mathrm{Na}$ additions of $1 \mathrm{mM}$ and up to $1 \mathrm{mM}$, respectively.

${ }^{\mathrm{d}}$ For Si-free electrolytes, data from treatments with $(\mathrm{P} / \mathrm{Fe})_{\text {init }}$ of 0 to 0.3 were omitted in model parameter refinement. 
Recovery of total As in fresh and aged suspensions
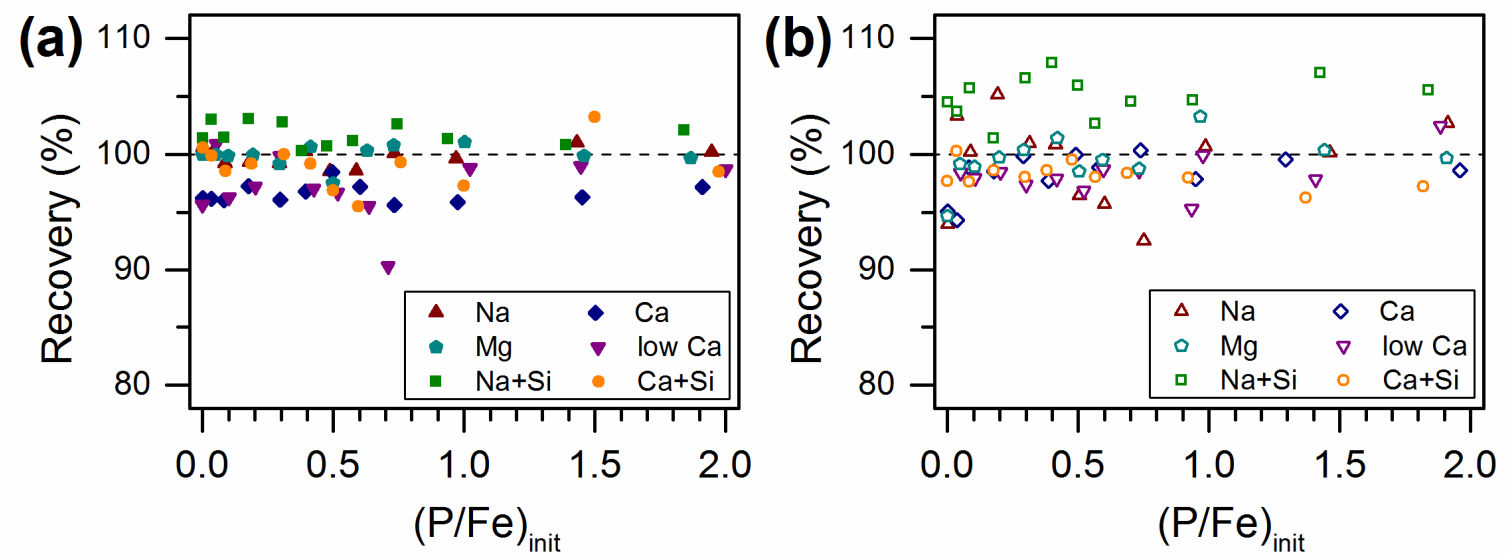

Figure S1. Recoveries of total As in the reaction suspensions after 4 hours (a) and 30 days (b) reaction times for the six different background electrolytes. Recovery was calculated by dividing total As after 4 hours or 30 days by the total initial As. 


\section{Correction for colloidal $\mathrm{P}$ and $\mathrm{As}(\mathrm{V})$ in fresh and aged $\mathrm{Na}$ and $\mathrm{Na}+\mathrm{Si}$ electrolytes}

arsenate
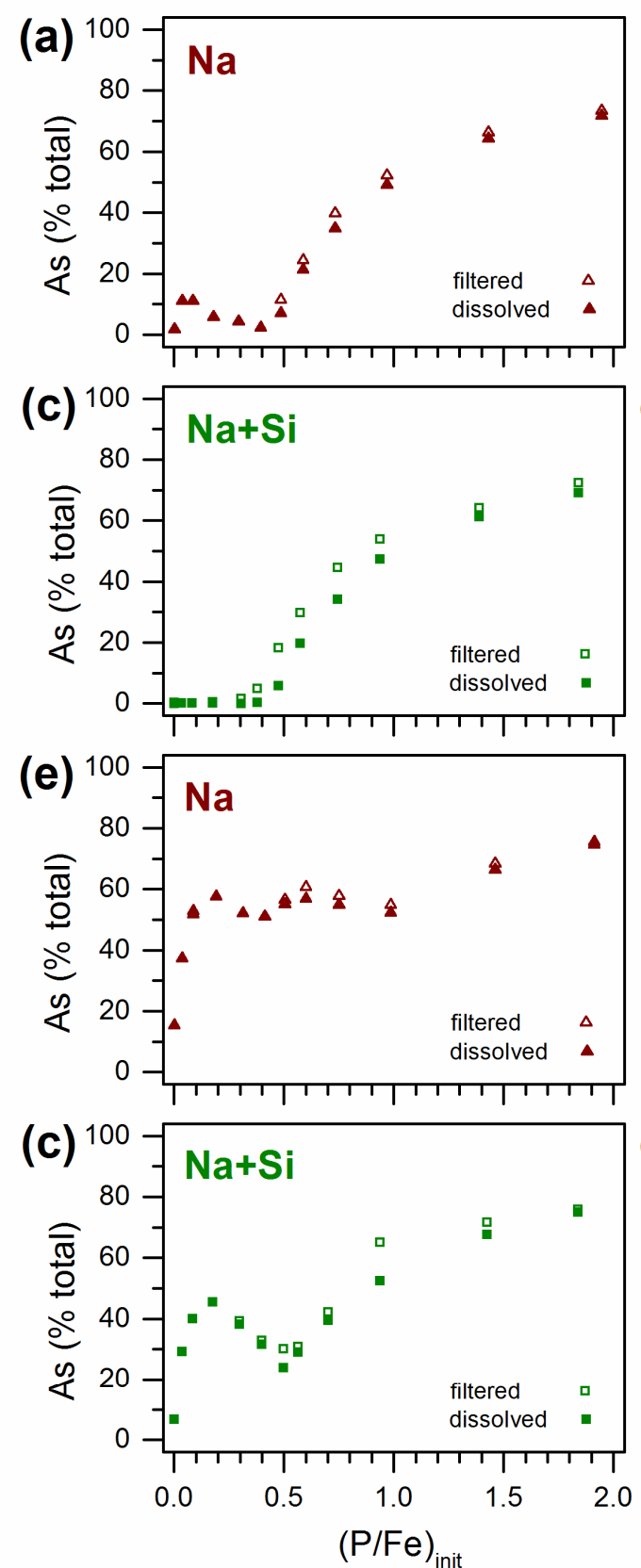

phosphate
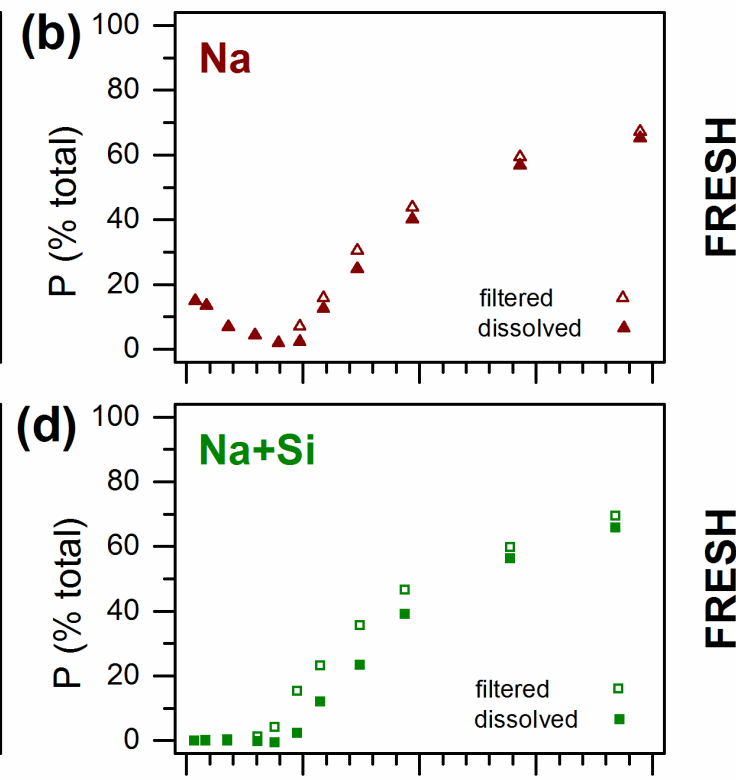

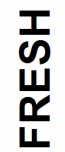

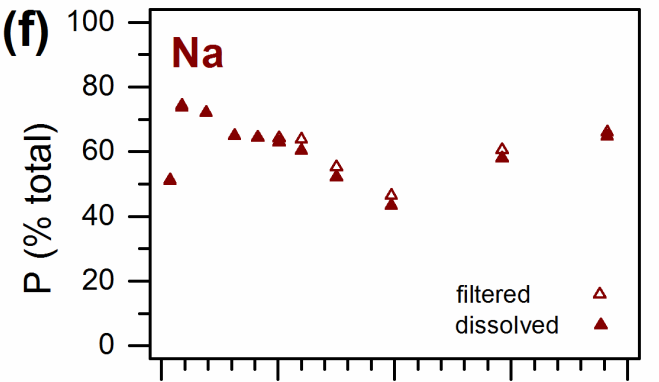

岂

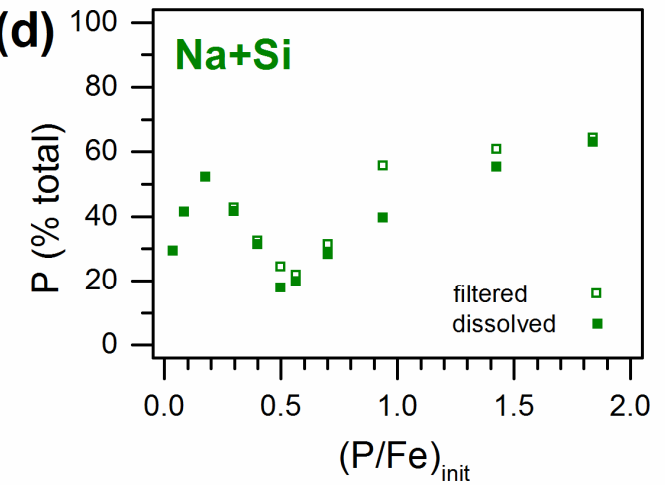

Figure S2. Comparison of measured concentrations of $\mathrm{P}$ and $\mathrm{As}(\mathrm{V})$ in filtered suspensions from the fresh and aged $\mathrm{Na}$ and $\mathrm{Na}+\mathrm{Si}$ electrolytes and dissolved concentrations obtained by correcting for colloidal $\mathrm{P}$ and $\mathrm{As}(\mathrm{V})$ (see text for details), expressed as percentage of total $\mathrm{P}$ and $\operatorname{As}(\mathrm{V})$ in suspension. 
For the aged $\mathrm{Na}$ and $\mathrm{Na}+\mathrm{Si}$ electrolytes, colloidal As or P typically accounted for $\leq 10 \%$ of the $\mathrm{As}_{\text {filt }}$ and $\mathrm{P}_{\text {filt, }}$, respectively, except for the treatments $\mathrm{Na}+\mathrm{Si} 0.5 \mathrm{~A}$ and $\mathrm{Na}+\mathrm{Si} 1.0 \mathrm{~A}$, where $\mathrm{X}_{\text {coll }} / \mathrm{X}_{\text {filt }}$ ranged between $20 \%$ and $29 \%$. In the fresh $\mathrm{Na}$ and $\mathrm{Na}+\mathrm{Si}$ electrolytes, the concentrations $\mathrm{X}_{\text {filt }}$ decreased from $\sim 67-71 \%$ at $(\mathrm{P} / \mathrm{Fe})_{\text {init }}$ of $\sim 2$ to $7-18 \sim$ at $(\mathrm{P} / \mathrm{Fe})_{\text {init }}$ of $\sim 0.5$ (in percent of total concentrations). Concomitantly, the estimated fraction of colloidal As and $\mathrm{P}$ in the filtered suspensions $\left(\mathrm{X}_{\mathrm{coll}} / \mathrm{X}_{\mathrm{filt}}\right)$ increased from $2-5 \%$ to $40-85 \%$. In fresh Na electrolyte suspensions with $(\mathrm{P} / \mathrm{Fe})_{\text {init }}$ of 0.4 and lower, colloidal As and $\mathrm{P}$ were negligible $\left(\mathrm{X}_{\text {coll }} / \mathrm{X}_{\text {filt }} \leq 2 \%\right)$. For the fresh $\mathrm{Na}+\mathrm{Si}$ electrolyte, on the other hand, the correction suggested that essentially all $\mathrm{As}_{\text {filt }}$ and $\mathrm{P}_{\text {filt }}$ at $(\mathrm{P} / \mathrm{Fe})_{\text {init }}$ of 0.4 and 0.3 was in colloidal from. For lower $(\mathrm{P} / \mathrm{Fe})_{\text {init }}$ from 0.3 to 0 , the concentrations of $\mathrm{Fe}, \mathrm{P}$ and $\mathrm{As}$ in the filtered suspensions were too low for a reliable estimation of the colloidal and dissolved fractions. However, filterable As and P concentrations corresponding to $<0.3 \%$ of their total spiked concentrations indicated the upper limit of dissolved As and P. Based on these considerations, the dissolved concentrations of As and $\mathrm{P}$ in fresh $\mathrm{Na}+\mathrm{Si}$ electrolyte suspensions with $(\mathrm{P} / \mathrm{Fe})_{\text {init }} \leq 0.5$ were set to zero for plots and data modeling on a linear scale, and were omitted in plots on a logarithmic scale. 